Piotr RÓŻAŃSKI

Krzysztof RADWAŃSKI

Marian NIESLER

Dariusz WOŹNIAK

Bogdan ZDONEK

Artur MAZUR

Valeriy PIDVYSOTS'KYY

Roman KUZIAK

Sieć Badawcza Łukasiewicz - Instytut Metalurgii Żelaza $\square$ Łukasiewicz Research Network - Institute of Ferrous Metallurgy

Grzegorz MARACHA

Wojciech FRAŚS

ArcelorMittal Poland S.A.

INNOWACYJNA STAL WYSOKOKRZEMOWA

Z REGULOWANĄ NISKĄ ZAWARTOŚCIĄ

ZANIECZYSZCZEŃ I WTRĄCEŃ NIEMETALICZNYCH

O KONTROLOWANEJ MORFOLOGII ORAZ

ODPOWIEDNIM POZIOMIE INHIBITORA AIN

Z PRZEZNACZENIEM NA WYSOKOJAKOŚCIOWE

BLACHY TRANSFORMATOROWE

\title{
INNOVATIVE HIGH-SILICON STEEL WITH REGULATED LOW CONTENT OF CONTAMINATIONS WITH CONTROLLED MORPHOLOGY AND APPROPRIATE LEVEL OF AIN INHIBITOR INTENDED FOR HIGH-QUALITY TRANSFORMER PLATES
}

$W$ artykule przedstawiono przebieg $i$ wyniki badań przemystowych wykonanych w ramach 1 Etapu projektu, którego końcowym celem jest opracowanie innowacyjnej stali elektrotechnicznej nowej generacji, przeznaczonej na blachy transformatorowe o wysokiej przenikalności magnetycznej (wysokiej indukcji 1,9 Ti matej stratności $0,8 \mathrm{~W} / \mathrm{kg}$ ) z ziarnem zorientowanym (typ HGO) wraz z technologia jej wytwarzania w zakresie: wytapiania w konwertorze z obróbka pozapiecowa uwzlędniajaca próżniowe odgazowanie stali w demonstracyjnej instalacji, ciagtego odlewania wlewków płaskich $i$ walcowania ich na goraco na pótwyrób do dalszego przerobu. Pozostate etapy roytwarzania blach transformatorowych obejmujace walcowanie na zimno, międzyoperacyjna obróbkę cieplna i cieplno-chemiczna oraz obróbke powierzchniowa stanowia tajemnica przedsiębiorstwa. $W$ ramach 1 Etapu projektu wykonano symulacje numeryczne i fizyczne wytapiania, odlewania $i$ walcowania na goraco stali o zatożonych parametrach jakościoreych, celem uzyskania materiatu do dalszych badań. Określono parametry wytapiania i odlewania zaperoniajace uzyskanie odpowiedniej jakości stali o maksymalnej zawartość tlenu catkoreitego 12 ppm $i$ udziale powierzchniowym wtracen niemetalicznych max. 0,05\%, oraz wymagania techniczno-technologiczne urządzenia do obróbki ciektej stali w próżni, stanowiącego instalację demonstracyjną,
The article presents the process and results of industrial tests carried out as part of the 1st Stage of the project, the final goal of which is to develop an innovative new-generation electrical steel designed for the manufacture of transformer plates with high magnetic permeability (high inductance of 1.9 T and low lossiness of $0.8 \mathrm{~W} / \mathrm{kg}$ ) and with oriented grain (HGO type) together with the technology of its production in the scope of: melting of steel in a converter with ladle treatment taking into account vacuum degassing of steel in a demonstration installation, continuous casting of flat ingots and their hot rolling for further processing. The remaining stages of transformer plate production, including cold rolling, inter-operational heat and thermo-chemical treatment, as well as surface treatment operations, are a trade secret. As part of the 1st Stage of the project, numerical and physical simulations of melting, casting and hot rolling of steel with assumed quality parameters were carried out in order to obtain material for further research. The melting and casting processes parameters were determined to ensure obtaining the appropriate quality of steel with a maximum total oxygen content of 12 ppm and the surface fraction of non-metallic inclusions of max. $0.05 \%$, technical and technological requirements for the device for liquid steel processing in vacuum constituting the demonstration installation were determined, and a rheolog- 
a także opracowano model reologiczny stali transformatorowej dla procesu walcowania blach na goraco, z użyciem którego przeprowadzono wstepne symulacje w celu uzyskania rozkładów temperatury, odkształcenia i prędkości odksztatcenia w walcowanym paśmie.

Stowa kluczowe: stal elektrotechniczna, zorientowane ziarno, modelowanie numeryczne i fizyczne, wytapianie, odlewanie, walcowanie na goraco.

\section{WPROWADZENIE}

Nowoczesne transformatory przyczyniają się do osiągnięcia zrównoważonego rozwoju gospodarczego. Wykorzystanie do ich produkcji blach transformatorowych o wysokiej przenikalności magnetycznej pozwala na ograniczenie zużycia energii elektrycznej przy obniżeniu zużycia materiałów do budowy transformatorów. Zastosowanie innowacyjnego w skali krajowej urządzenia do obróbki pozapiecowej ciekłej stali (dwukomorowego urzadzenia typu VTD wykorzystujacego pompy mechaniczne $\mathrm{w}$ miejsce strumienic parowych do wytwarzania próżni) i zastąpienie dwukadziowej technologii wytwarzania stali elektrotechnicznej technologia jednokadziową zmniejszy jednostkowe imisje $\mathrm{CO}_{2}$ na tonę stali.

Przewiduje się, że w wyniku realizacji projektu zostaną opracowane i wdrożone do produkcji w kraju ulepszone stale o zorientowanym ziarnie oznaczane skrótem HGO. Charakteryzować się będą wyższą indukcyjnością w porównaniu $\mathrm{z}$ obecnie produkowanymi stalami wynoszącą $1,9 \mathrm{~T}$ i niższą o $20 \div 25 \%$ stratnością wynoszącą $0,8 \mathrm{~W} / \mathrm{kg}$.

Pożądane właściwości blach transformatorowych kształtowane są w procesie wtórnej rekrystalizacji podczas wyżarzania blachy zimnowalcowanej. W jej wyniku zachodzi rozrost pierwotnie zrekrystalizowanych ziarn o orientacji krystalograficznej (110) [001] (tekstura Gossa) o rozmiarach od około $10 \mu \mathrm{m}$ do $5 \mathrm{~mm}$ lub większych. Kierunek [001] łatwej magnetyzacji jest wtedy równoległy do kierunku walcowania.

Wysokie właściwości użytkowe tych stali założono uzyskać w wyniku zapewnienia odpowiedniego:

- składu chemicznego, w tym: niskiej zawartości tlenu, węgla, regulowanej zawartości siarki, fosforu i azotu, a także odpowiedniej ilości glinu, krzemu i manganu oraz dodatku miedzi i/lub cyny

- zaawansowanej technologii walcowania na zimno z międzyoperacyjną obróbką cieplną

- wspomnianego już zorientowanego ziarna w procesie wyżarzania rekrystalizującego dzięki zastosowaniu inhibitorów - odpowiednich wydzieleń wpływających na rozwój tekstury Gossa.

Inhibitory pożądanej tekstury blachy transformatorowej to bardzo drobne cząstki drugiej fazy takie jak: siarczki manganu i selenu, azotki glinu i boru, a także wydzielenia metaliczne pierwiastków segregujących w granicach ziarn i hamujących ich migrację, np.: Sb i Sn [1-4].

Drobne wydzielenia AlN (stale Hi-B) kontrolują przebieg rozrostu zrekrystalizowanych ziarn w procesie pierwotnej rekrystalizacji i zapewniają uzyskanie pożądanego przebiegu wtórnej rekrystalizacji [5]. Wymaga to odpowiedniego rozkładu wielkości, ułamka objętości i równomiernego rozmieszczenia wydzieleń AlN w czasie całego procesu od wytapiania stali do wyżarzania blachy zimnowalcowanej. Niezbędne jest również zachowanie w strukturze niewielkiej zawartości austenitu (resztkowego) w celu rozpuszczenia AlN podczas wygrzewania i wydzielenia licznych drobnych ical model of transformer steel for the sheet hot-rolling process was developed, with the use of which preliminary simulations were carried out to obtain temperature, deformation and strain rates in the rolled strip.

Keywords: electrical steel, oriented grain, numerical and physical modelling, melting, casting, hot rolling.

\section{INTRODUCTION}

Modern transformers contribute to achieving sustainable economic development. The use of transformer sheets with high magnetic permeability for their production allows reducing the consumption of electricity while reducing the consumption of materials for transformer construction. The use of a device for liquid metallurgy treatment of liquid steel (two-chamber device type VTD using mechanical pumps in place of steam jets to generate vacuum), innovative on the national scale, and replacement of double ladle technology for the production of electrical steel with single-ladle technology will reduce specific $\mathrm{CO}_{2}$ emissions per ton of steel.

It is anticipated that as a result of project implementation, improved grain oriented steels referred to with the abbreviation HGO will be developed and implemented for domestic production. They will be characterised by a higher inductance compared to currently produced steels, amounting to $1.9 \mathrm{~T}$ and lossiness lower by $20-25 \%$ of $0.8 \mathrm{~W} / \mathrm{kg}$.

The desired properties of transformer sheets are shaped in the process of secondary recrystallisation during annealing of cold-rolled sheets. As a result, originally recrystallised grains with a crystallographic orientation of (110) [001] (Goss texture) with sizes from approx. $10 \mu \mathrm{m}$ to $5 \mathrm{~mm}$ or larger grow. The direction [001] of easy magnetisation is then parallel to the rolling direction.

High performance properties of these steels were assumed to be obtained as a result of ensuring adequate:

- chemical composition, including: low oxygen and carbon content, adjustable sulphur content, phosphorus and nitrogen content, as well as adequate amounts of aluminium, silicon and manganese, and the addition of copper and/or tin,

- advanced cold rolling technology with inter-operational heat treatment,

- already mentioned oriented grain in the process of recrystallisation annealing thanks to the use of inhibitors - appropriate precipitates affecting the development of Goss texture.

Inhibitors of the desired transformer sheet texture are very fine second-phase particles such as: manganese and selenium sulphides, aluminium and boron nitrides, as well as metallic precipitates of elements segregating within grain boundaries and inhibiting their migration, e.g. $\mathrm{Sb}$ and $\mathrm{Sn}$ [1-4].

Fine AlN precipitates (Hi-B steels) control the growth of recrystallised grains in the process of primary recrystallisation and ensure that the desired course of secondary recrystallisation is achieved [5]. This requires an appropriate distribution of size and volume fraction, and even distribution of AlN precipitates throughout the process, from steel melting to annealing of cold-rolled sheet. It is also necessary to keep a low content of (residual) austenite in the structure in order to dissolve AlN during annealing and to precipitate 
cząstek AlN podczas chłodzenia wyżarzonej blachy gorąco walcowanej.

Morfologię inhibitorów można kształtować za pomocą dodatku niewielkich ilości pierwiastków stopowych niewiążących się z krzemem, czy też z inhibitorem, wywołując zmianę w przebiegu wtórnej rekrystalizacji. Na przykład dodatek niewielkiej ilości cyny stabilizuje przebieg wtórnej rekrystalizacji [6].

\section{BADANIA WEASNE}

Celem Etapu 1 projektu było:

1. Opracowanie doświadczalnej technologii wytapiania innowacyjnej stali elektrotechnicznej

2. Określenie parametrów wytapiania i odlewania zapewniających uzyskanie odpowiedniej jakości stali o maksymalnej zawartości tlenu całkowitego nie większej niż 12 ppm, udziale powierzchniowym wtrąceń niemetalicznych max. $0,05 \%$

3. Określenie wymagań techniczno-technologicznych instalacji demonstracyjnej - urządzenia do obróbki ciekłej stali w próżni.

Opracowana technologia wytapiania i odlewania z uwzględnieniem pozapiecowej obróbki próżniowej stali transformatorowej nowej generacji ma zapewnić uzyskanie założonych wysokich właściwości użytkowych finalnego wyrobu w postaci blach transformatorowych, czyli wysokiej przenikalności magnetycznej i małej stratności (o indukcji min. 1,9 T i stratności na poziomie $0,80 \mathrm{~W} / \mathrm{kg}$ ).

Zakres badań obją:

- Obliczenia numeryczne, wytopy laboratoryjne, walcowanie na gorąco blach, symulacje fizyczne z wykorzystaniem Gleeble

- Identyfikację wtrąceń niemetalicznych obejmującą mikroanalizę składu chemicznego, wyznaczenie udziału powierzchniowego i ocenę morfologii

- Badania strukturalne i właściwości mechanicznych: blach po walcowaniu na gorąco, próbek po eksperymentach $\mathrm{z}$ użyciem symulatora Gleeble.

Opracowana w ramach Etapu 1 technologia wytapiania i odlewania nowego gatunku stali będzie stanowić podstawę do wykonania przemysłowych wytopów badawczych. W oparciu o dostępną wiedzę i doświadczenie zaprojektowano składy chemiczne stali przeznaczonych na blachy transformatorowe. Niezbędnym warunkiem wytworzenia pożądanej tekstury blachy jest występowanie w stali bardzo drobnych cząstek (nazywanych inhibitorami rozrostu ziarna) hamujących rozrost ziarn o niekorzystnej orientacji krystalograficznej. Jako inhibitory rozrostu tych ziarn wykorzystuje się drobne wydzielenia siarczków manganu, selenu, azotki glinu i boru, ale także pierwiastki segregujące do granic ziarn, hamujące ich migrację, takie jak antymon i cyna $[1-4,7]$. Z tego powodu zawartości pierwiastków, takich jak: C, N, O, S, Sn, które tworzą wydzielenia i wtrącenia, regulowane są w ściśle określonych przedziałach.

Zawartość węgla w tych stalach, na etapie wytwarzania blach walcowanych na gorąco, może wynosić od 0,04 do 0,07\%. Przed zabiegiem wtórnej rekrystalizacji musi ona być zmniejszona na drodze odwęglania do poziomu poniżej $0,003 \%$. W przeciwnym razie tworzące się w gotowym wyrobie węgliki wywołują zjawiska rozproszenia, przez wzajemne oddziaływanie ze ściankami domen magnetycznych, zwiększając stratność.

Azot tworząc azotki glinu przeciwdziała rozrostowi ziarna, jak również sprzyja powstawaniu tekstury Gossa, przy numerous fine AlN particles during cooling of annealed hotrolled sheet.

The morphology of inhibitors can be shaped using the addition of small amounts of alloying elements that do not bind to silicon or an inhibitor causing a change in secondary recrystallisation. For example, the addition of a small amount of tin stabilises the course of secondary recrystallisation [6].

\section{OWN RESEARCH}

The goal of Stage 1 of the project was:

1. Development of experimental melting technology for innovative electrical steel

2. Determination of melting and casting parameters ensuring the quality of steel with a maximum total oxygen content of not more than $12 \mathrm{ppm}$, surface fraction of non-metallic inclusions of max. $0.05 \%$

3. Determination of technical and technological requirements of the demonstration installation - equipment for processing liquid steel in vacuum.

The developed technology of melting and casting, taking into account the next-generation secondary vacuum treatment of transformer steel is to ensure the achievement of the assumed high performance properties of the final product in the form of transformer sheets, i.e. high magnetic permeability and low lossiness (with an induction of at least $1.9 \mathrm{~T}$ and a lossiness of $0.80 \mathrm{~W} / \mathrm{kg}$ ).

The scope of the study included:

- Numerical calculations, laboratory melts, hot rolling of sheets, physical simulations using Gleeble

- Identification of non-metallic inclusions including microanalysis of the chemical composition, determination of surface fraction and assessment of morphology

- Studies on structure and mechanical properties: on sheets after hot rolling, samples after experiments using a Gleeble simulator.

The technology for melting and casting of a new steel grade developed as part of Stage 1 will provide the basis for industrial research melts. Chemical compositions of steels intended for transformer sheets were designed based on the available knowledge and experience. An indispensable condition for producing the desired sheet texture is the presence of very fine particles (called grain growth inhibitors) in steel that inhibit grain growth with unfavourable crystallographic orientation. Fine manganese and selenium sulphides, aluminium and boron nitrides, as well as elements segregating to grain boundaries, inhibiting their migration, such as antimony and tin, are used as inhibitors of the growth of these grains $[1-4,7]$. For this reason, the content of elements such as $\mathrm{C}, \mathrm{N}, \mathrm{O}, \mathrm{S}, \mathrm{Sn}$, which form precipitates and inclusions, are regulated in strictly defined intervals.

The carbon content in these steels, at the sheet hot-rolling production stage, may be from 0.04 to $0.07 \%$. Before secondary recrystallisation, it must be reduced by decarburisation to below $0.003 \%$. Otherwise, carbides formed in the finished product cause scattering phenomena, by interacting with the walls of magnetic domains, increasing lossiness.

By creating aluminium nitrides, nitrogen prevents grain growth as well as promotes the formation of Goss texture, when it dissolves in the process of high-temperature annealing of the coils. Its too low content prevents the formation of the required amount of grain growth inhibitor, and its excessive content may cause defects (punctures) in the finished product. The sulphur content is regulated at a sufficiently 
rozpuszczaniu się w procesie wysokotemperaturowego wyżarzania kręgów. Zbyt niska jego zawartość uniemożliwia utworzenie wymaganej ilości inhibitora rozrostu ziarna, a nadmierna jego zawartość grozi powstawaniem wad (nakłuć) w gotowym wyrobie. Zawartość siarki jest regulowana na odpowiednio niskim poziomie dla zapewnienia utworzenia wystarczającego ułamka objętościowego wtrąceń siarczku manganu (MnS), wymaganego do właściwego przebiegu wtórnej rekrystalizacji. Nadmierna ilość siarki przyczynia się do powstawania grubych wydzieleń $\mathrm{MnS}$, nieskutecznych przy wtórnej rekrystalizacji.

Cyna i fosfor wpływają na poprawę właściwości magnetycznych gotowego wyrobu. Wpływ ten wynika ze zdolności cyny do segregowania na powierzchni czastek fazy wtórnej, zwiększając ich trwałość i sprzyjając drobnym wydzieleniom. Pozytywny wpływ fosforu wynika ze zdolności do segregowania do granic ziarn, zmniejszając ich ruchliwość i przyczyniając się w ten sposób do regulacji rozrostu ziarn podczas wtórnej rekrystalizacji.

Konieczność ograniczenia poziomu tlenu w stali wynika z potrzeby wyeliminowania możliwości tworzenia się wtrąceń tlenkowych. Uwzględniając ww. założenia oraz względy ekonomiczne i technologiczne, do badań wytypowano stale $\mathrm{z}$ regulowaną zawartością siarki i fosforu w wersji z cyną i bez cyny, różniące się zawartością węgla, azotu i glinu.

- C $0,030 \div 0,065 \%$

- Mn $0,08 \div 0,25 \%$

- Si $\quad 3,10 \div 3,30 \%$

- P $0,018 \div 0,028 \%$

- $\mathrm{Al} \quad 0,010 \div 0,030 \%$

- $\mathrm{Cr} \quad 0,08 \div 0,20 \%$

- Sn o lub $0,02 \div 0,07 \%$

- N $0,006 \div 0,010 \%$

\subsection{SYMULACJE NUMERYCZNE}

Wykonanie badawczych wytopów laboratoryjnych poprzedzono przeprowadzeniem symulacji numerycznych. Obliczenia te miały na celu wytypowanie zawężonych składów chemicznych stali do dalszych badań i zostały przeprowadzone za pomocą programów:

- FactSage 7.1 - w zakresie przebiegu procesu krzepnięcia oraz przebiegu wydzielania wtrąceń niemetalicznych i faz międzymetalicznych (identyfikacja ich rodzaju i udziału), decydujących o właściwościach stali, w zależności od poziomu tlenu całkowitego i pierwiastków wchodzących w skład tych wydzieleń, takich jak: azot, glin, chrom i siarka

- JMatPro - wykorzystany do zdefiniowania charakterystycznych danych materiałowych niezbędnych w symulacjach procesu ciągłego odlewania stali, jak: zmiana udziału fazy stałej w funkcji temperatury, przewodność cieplna, gęstość, lepkość, entalpia

- ProCast - celem określenia parametrów procesu ciągłego odlewania

- Dictra - obliczenia procesów mikrosegregacji w krzepnącym wlewku ciągłym.

\subsubsection{Symulacje procesu krzepnięcia stali z wykorzystaniem programu FactSage}

Celem symulacji wykonanych za pomocą oprogramowania termochemicznego FactSage 7.1 było określenie przebiegu procesu krzepnięcia stali o danym składzie chemicznym. W ich wyniku wyznaczone zostały przybliżone temperatury solidus i likwidus dla stali o zaproponowanych składach chemicznych, rodzaj i udział faz, w tym wtrąceń niemetalicznych i faz międzymetalicznych, jak też zakresów temperatur low level to ensure the formation of a sufficient volume fraction of manganese sulphide inclusions (MnS), required for the proper course of secondary recrystallisation. Excessive amount of sulphur contributes to the formation of thick $\mathrm{MnS}$ precipitates, which are ineffective in secondary recrystallisation.

Tin and phosphorus improve the magnetic properties of the finished product. This effect results from the ability of tin to segregate secondary phase particles on the surface, increasing their durability and favouring fine precipitation. The positive effect of phosphorus is due to the ability to segregate to grain boundaries, reducing their mobility and thus contributing to the regulation of grain growth during secondary recrystallisation.

The need to limit the oxygen level in steel results from the need to eliminate the possibility of oxide inclusions. Considering the above-mentioned assumptions as well as economic and technological issues, steels with regulated sulphur and phosphorus content in the version with and without tin were selected, differing in the content of carbon, nitrogen and aluminium.
- C $\quad 0.030-0.065 \%$
- Mn $0.08-0.25 \%$
- $\mathrm{Si} \quad 3.10-3.30 \%$
- P $0.018-0.028 \%$
- $\mathrm{Al} \quad 0.010-0.030 \%$
- $\mathrm{Cr} \quad 0.08-0.20 \%$
- Sn 0 or $0.02-0.07 \%$
- N $\quad 0.006-0.010 \%$

\subsection{NUMERICAL SIMULATIONS}

Research laboratory melts was preceded by numerical simulations. These calculations were used to select narrowed chemical compositions of steel for further research and were carried out using the following programs:

- FactSage 7.1 - in terms of the solidification process and the course of non-metallic inclusions and intermetallic phases precipitation (identification of their type and share), determining the properties of steel, depending on the level of total oxygen and elements included in these precipitates, such as nitrogen, aluminium, chromium and sulphur,

- JMatPro - used to define the characteristic material data necessary for simulations of the continuous steel casting process, such as: change of the solid phase share as a function of temperature, thermal conductivity, density, viscosity, enthalpy

- ProCast - to determine the parameters of the continuous casting process

- Dictra - calculation of the processes of micro-segregation in a solidifying continuous ingot.

\subsubsection{Steel solidification process simulations using the FactSage program}

The purpose of the simulations performed with the use of FactSage 7.1 thermochemical software was to determine the course of the solidification process of steel with a given chemical composition. As a result, approximate solidus and liquidus temperatures for steels with the proposed chemical compositions, type and share of phases, including non-metallic inclusions and intermetallic phases, as well as ranges 
ich wydzielania i występowania w stali w stanie stałym po zakrzepnięciu.

Taki sam program obliczeń zastosowano dla wytopu przemysłowego wykonanego wyprzedzająco w obecnych warunkach technicznych. Zakresy zmienności parametrów użytych w obliczeniach przedstawiono w tabeli 1. Uzyskane wyniki symulacji porównano z wynikami analizy wtrąceń niemetalicznych, wykonanej na próbkach stali w stanie po odlaniu, z wykorzystaniem mikroskopii skaningowej.

Do najważniejszych ustaleń z przeprowadzonych symulacji należy zaliczyć to, że przy założonych składach chemicznych stali transformatorowych dla zawartości $10 \div 12 \mathrm{ppm}$ tlenu całkowitego:

- możliwe jest uzyskanie pożądanych wydzieleń azotku AlN (Rys. 1b), przy czym przy danej zawartości azotu istnieje graniczna zawartość glinu, po przekroczeniu której nie zwiększa się udział fazy AlN (dla 0,008\% N wynosi ona około 0,0165\% Al (Rys. If)

- istnieje prawdopodobieństwo wystapienia w stali w stanie stałym po zakrzepnięciu węglików typu $\mathrm{M}_{3} \mathrm{C}_{2}\left(\mathrm{Cr}_{3} \mathrm{C}_{2}\right)$ i $\mathrm{M}_{7} \mathrm{C}_{3}\left(\mathrm{Mn}_{7} \mathrm{C}_{3} \mathrm{z}\right.$ niewielką zawartością $\mathrm{Fe}_{7} \mathrm{C}_{3}$ i $\left.\mathrm{Cr}_{7} \mathrm{C}_{3}\right)$ nawet dla składów stali przy dolnej granicy zawartości węgla $0,045 \%$, niskiej zawartości chromu $(0,12 \%)$ i poziomie tlenu całkowitego 10 ppm (Rys. 1b).

Należy podkreślić uzyskanie dużej zgodności wyników symulacji z wynikami analizy jakościowej wtrąceń niemetalicznych przeprowadzonej dla stali z wyprzedzającego wytopu przemysłowego. of their precipitation and occurrence in solid steel after solidification were determined.

The same calculation program was used for industrial melting carried out in advance at current technical conditions. The ranges of variability of parameters used in the calculations are presented in Table 1 . The obtained simulation results were compared with the results of the analysis of non-metallic inclusions carried out on cast steel samples, using scanning microscopy.

The most important findings from the simulations carried out include the fact that with assumed chemical compositions of transformer steels for the content of 10-12 ppm of total oxygen:

- it is possible to obtain the desired AlN nitride precipitates (Fig. 1b), but at a given nitrogen content there is a limit aluminium content, beyond which the proportion of the AlN phase does not increase (for $0.008 \% \mathrm{~N}$ it is about $0.0165 \% \mathrm{Al}$ (Fig. If )

- there is a likelihood of solid steel occurring after solidification of $\mathrm{M}_{3} \mathrm{C}_{2}\left(\mathrm{Cr}_{3} \mathrm{C}_{2}\right)$ and $\mathrm{M}_{7} \mathrm{C}_{3}\left(\mathrm{Mn}_{7} \mathrm{C}_{3}\right.$ with low $\mathrm{Fe}_{7} \mathrm{C}_{3}$ and $\mathrm{Cr}_{7} \mathrm{C}_{3}$ content) carbides even for steel compositions at a lower carbon content of $0.045 \%$, low chromium content (0.12\%) and total oxygen level of 10 ppm (Fig. 1b)

It should be emphasised that the simulation results are highly consistent with the results of the qualitative analysis of non-metallic inclusions carried out for steel from the preceding industrial melt.

Tabela 1. Zakresy zmienności zawartości pierwiastków, [\% mas.] i temperatury użyte w obliczeniach, $\left[{ }^{\circ} \mathrm{C}\right]$

Table 1. Ranges of variability of element content, [mass \%] and temperature used in calculations, $\left[{ }^{\circ} \mathrm{C}\right]$

\begin{tabular}{|c|c|c|}
\hline Lp. I No. & Parametr 口 Parameter & Zakres zmienności = Variability range \\
\hline 1 & $\mathrm{O}_{\mathrm{C}}$ & $0,0005 \div 0,0012 \%$ \\
\hline 2 & $\mathrm{~N}$ & $0 \div 0,01 \%$ \\
\hline 3 & $\mathrm{Al}$ & $0,012 \div 0,025 \%$ \\
\hline 4 & Sn & $0 \div 0,1 \%$ \\
\hline 5 & Temperatura $\square$ Temperature & $1630 \div 20^{\circ} \mathrm{C}$ (chłodzenie cooling) \\
\hline
\end{tabular}

$0,045 \mathrm{C}+0,15 \mathrm{Mn}+3,2 \mathrm{Si}+0,023 \mathrm{P}+0,006 \mathrm{~S}+0,12 \mathrm{Cr}+0,02 \mathrm{Al}+0,008 \mathrm{~N}+0,0010+96,427 \mathrm{Fe}$

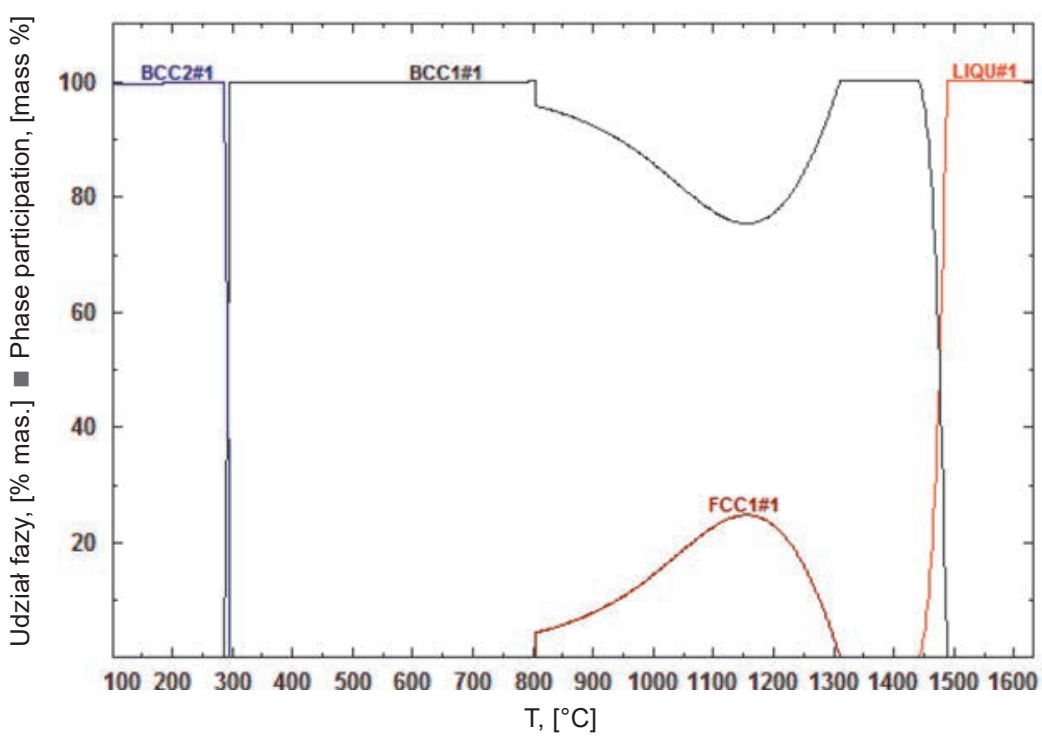

Rys. 1a. Przebieg procesu krzepnięcia stali o podanym wyżej składzie; symulacja według modelu równowagowego (Equilibrium cooling); temperatura likwidus: $1485,9^{\circ} \mathrm{C}$, temperatura solidus: $1438,7^{\circ} \mathrm{C}$

Fig. 1a. Course of the solidification process of steel of the above composition; simulation according to the equilibrium cooling model; liquidus temperature: $1485.9^{\circ} \mathrm{C}$, solidus temperature: $1438.7^{\circ} \mathrm{C}$ 


\section{$0,045 \mathrm{C}+0,15 \mathrm{Mn}+3,2 \mathrm{Si}+0,023 \mathrm{P}+0,006 \mathrm{~S}+0,12 \mathrm{Cr}+0,05 \mathrm{Sn}+0,02 \mathrm{Al}+0,008 \mathrm{~N}+0,0010+96,327 \mathrm{Fe}$}

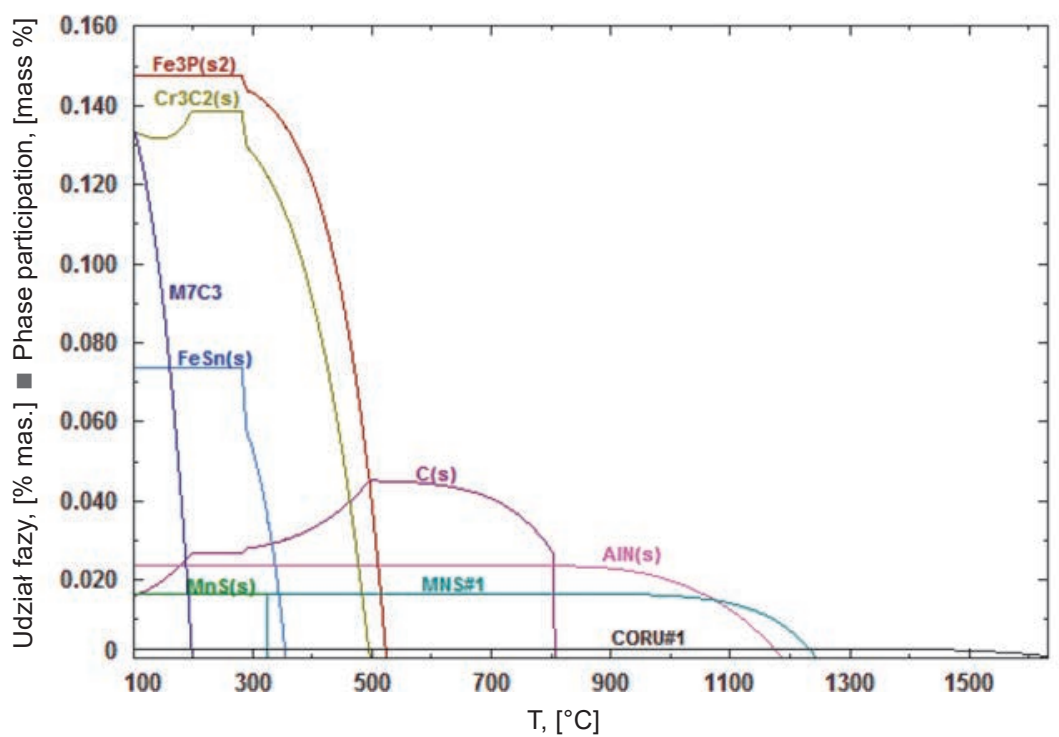

Rys. 1b. Przebieg wydzielania faz w czasie procesu ochładzania stali o podanym wyżej składzie - wydzielenia w postaci wtrąceń niemetalicznych i faz międzymetalicznych. UWAGA: linia C(s) przedstawia węgiel obecny w cementycie

Fig. 1b. Course of phase precipitation during the cooling process of steel with the composition given above - precipitates in the form of non-metallic inclusions and intermetallic phases. NOTE: line $C(s)$ presents the carbon present in cementite

\section{$0,045 \mathrm{C}+0,15 \mathrm{Mn}+3,2 \mathrm{Si}+0,023 \mathrm{P}+0,006 \mathrm{~S}+0.12 \mathrm{Cr}+0,05 \mathrm{Sn}+0,02 \mathrm{Al}+0,008 \mathrm{~N}+0,0010+\mathrm{Fe}$ reszta}

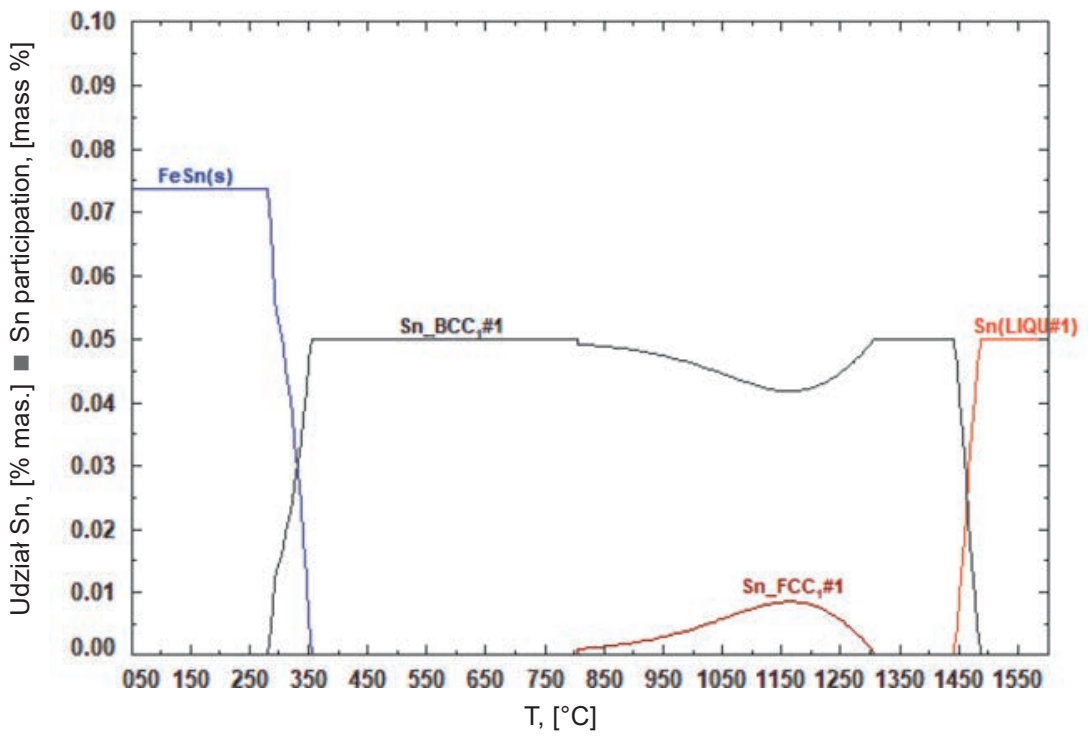

Rys. 1c. Zmiany postaci występowania cyny w warunkach równowagowych na przykładzie procesu krzepnięcia stali o podanym wyżej składzie chemicznym

Fig. 1c. Changes in the form of tin occurrence at equilibrium conditions on the example of solidification process of steel with the abovementioned chemical composition

Przykładowe wyniki symulacji wykonanych przy użyciu oprogramowania FactSage 7.1 przedstawiono na rys. 1a-e.

\subsubsection{Symulacje procesu ciągłego odlewania}

Symulacje te objęły:

- określenie warunków początkowych i brzegowych, w tym zdefiniowanie danych materiałowych charakteryzujących dany gatunek stali, jak: zmiana udziału fazy stałej w funkcji temperatury, przewodność cieplna, gęstość, lepkość, entalpia
Examples of results of simulations performed using the FactSage 7.1 software are shown in Figs. 1a-e.

\subsubsection{Continuous casting process simulations}

These simulations included:

- determination of initial and boundary conditions, including the definition of material data characterising a given steel grade, such as: change in the share of solid phase as a function of temperature, thermal conductivity, density, viscosity, enthalpy 


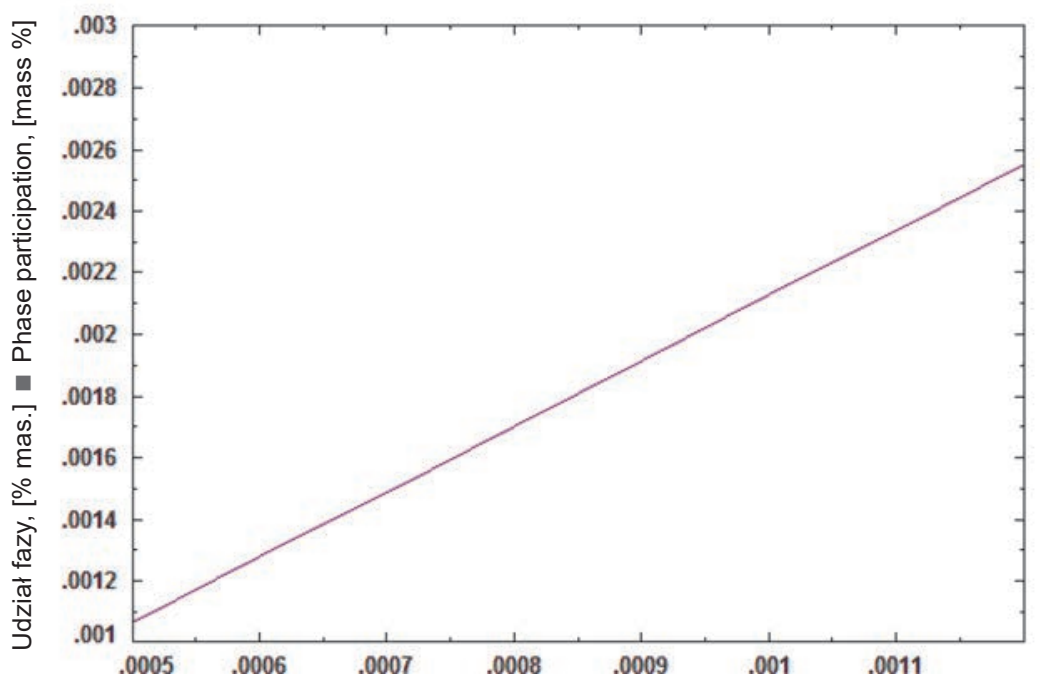

Zawartość tlenu całkowitego w stali, [\% mas.] — Total oxygen content in steel, [mass \%]

Rys. 1d . Zmiana zawartości wtrąceń korundowych $\left(\mathrm{M}_{2} \mathrm{O}_{3}\right.$ : złożonych z $\mathrm{Al}_{2} \mathrm{O}_{3} \mathrm{z}$ bardzo niewielkimi - śladowymi zawartościami Cr $\mathbf{O}_{2} \mathrm{O}_{3}$ i Fe $\left.\mathrm{O}_{3}\right)$ w stali o podanym wyżej składzie chemicznym w temperaturze $20^{\circ} \mathrm{C}$ w funkcji udziału tlenu

Fig. 1d. Change in the content of corundum inclusions $\left(\mathrm{M}_{2} \mathrm{O}_{3}\right.$ : composed of $\mathrm{Al}_{2} \mathrm{O}_{3}$ with very low - trace content of Cr $\mathrm{O}_{3}$ and $\left.\mathrm{Fe}_{2} \mathrm{O}_{3}\right)$ in steel with the above chemical composition at $20^{\circ} \mathrm{C}$ as a function of oxygen content

\section{$0,045 \mathrm{C}+0,15 \mathrm{Mn}+3,2 \mathrm{Si}+0,023 \mathrm{P}+0,006 \mathrm{~S}+0,12 \mathrm{Cr}+0,05 \mathrm{Sn}+\mathrm{xAl}+0,008 \mathrm{~N}+0,0010+\mathrm{Fe}$ reszta}

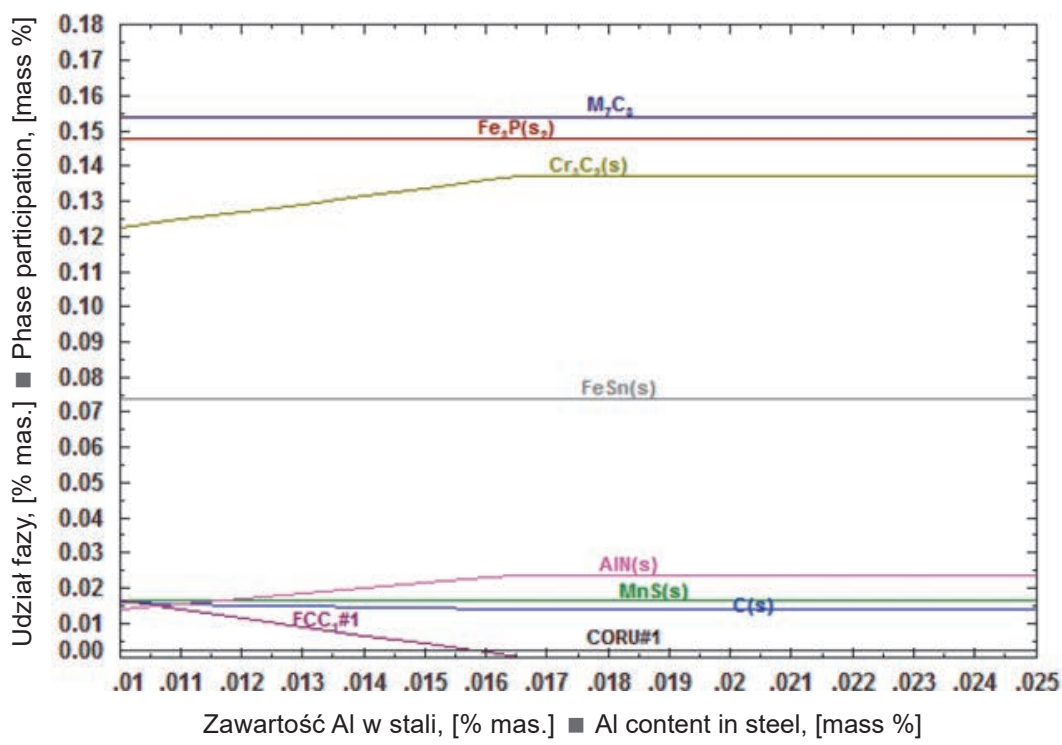

Rys. 1e. Zmiana zawartości wydzieleń w postaci węglików, MnS, AlN i faz międzymetalicznych w stali o podanym wyżej składzie chemicznym (w temperaturze $20^{\circ} \mathrm{C}$ ) w funkcji zawartości glinu w stali

Fig. 1e. Change in the content of precipitates in the form of carbides, MnS, AlN and intermetallic phases in steel with the above-mentioned chemical composition $\left(a^{2} 0^{\circ} \mathrm{C}\right.$ ) as a function of aluminium content in steel

- wyznaczenie parametrów odlewania ciągłego dla przewidywanych zakresów składów chemicznych stali na podstawie:

- obliczeń rozkładu temperatury i udziału fazy stałej na przekroju poprzecznym pasma (Rys. 2)

- prognozowania zasięgu fazy ciekłej w czasie odlewania stali (Rys. 3)

- prognozowania grubości naskórka wlewka po wyjściu z krystalizatora.

Najważniejszym wnioskiem z przeprowadzonych symulacji jest stwierdzenie, że stal elektrotechniczna o składzie
- determination of continuous casting parameters for the anticipated ranges of chemical compositions of the steels on the basis of:

- calculations of temperature distribution and solid phase content on the cross section of the strip (Fig. 2)

- forecast of the range of the liquid phase during steel casting (Fig. 3)

- forecast of the ingot shroud thickness after exiting the crystalliser.

The most important conclusion from the conducted simulations is that electrical steel with a chemical composition 
A)

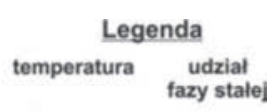

a)

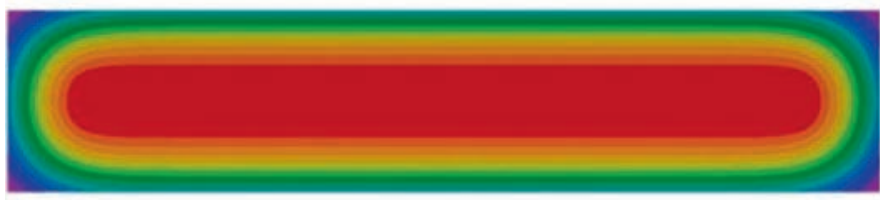

b)

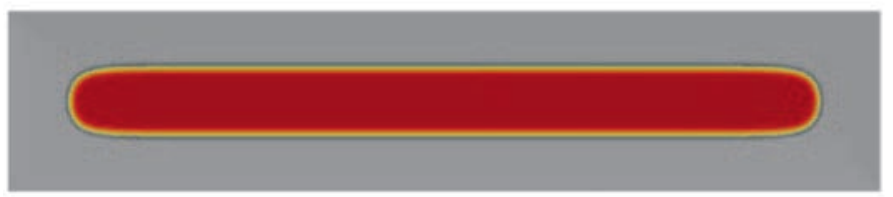

B)

a)

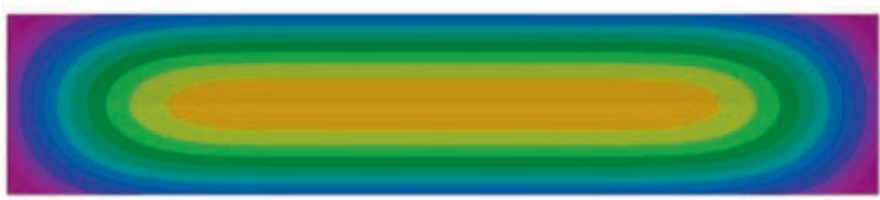

b)

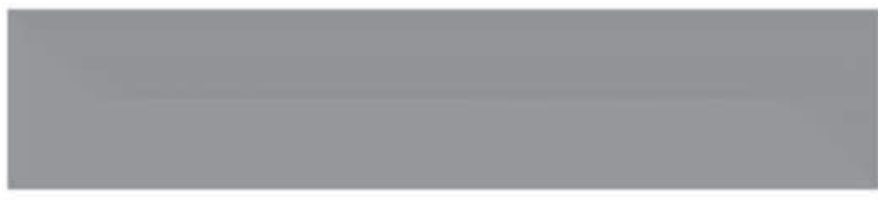

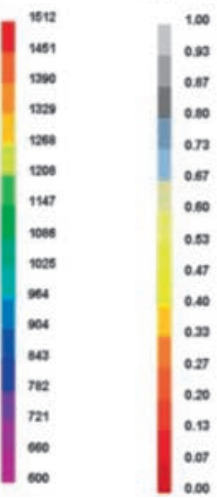

Legenda

temperatura $\begin{gathered}\text { udzial } \\ \text { fazy stalej }\end{gathered}$

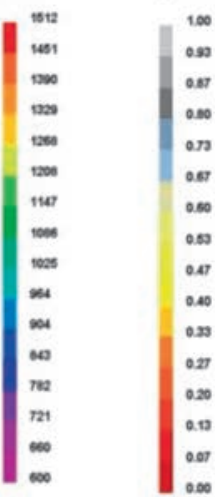

Rys. 2. Prognozowany rozkład temperatury (A) i udziału fazy stałej (B) na przekroju poprzecznym wlewka ciągłego: a) po wyjściu z krystalizatora, b) w czasie odginania pasma, (obliczone z wykorzystaniem programu ProCAST, skład chemiczny stali: 0,048\% C, 0,15\% Mn, $3,20 \% \mathrm{Si}, 0,023 \% \mathrm{P}, 0,006 \% \mathrm{~S}, 0,019 \% \mathrm{Al}, 0,12 \% \mathrm{Cr}, 0,05 \% \mathrm{Sn}, 0,008 \% \mathrm{~N}, 0,0012 \% \mathrm{O}_{\mathrm{C}}$, przekrój wlewka: $220 \times 1065 \mathrm{~mm}, V_{\mathrm{c}}=0,80 \mathrm{~m} / \mathrm{min}$, $T_{\text {odl. }}=1512^{\circ} \mathrm{C}$ )

Fig. 2. Forecast distribution of temperature (A) and solid phase content (B) on the cross-section of a continuous ingot: a) after exiting the crystalliser, b) during strip bending, (calculated using the ProCAST program, chemical composition of the steel: 0.048\% C, 0.15\% Mn, $3.20 \% \mathrm{Si}, 0.023 \% \mathrm{P}, 0.006 \% \mathrm{~S}, 0.019 \% \mathrm{Al}, 0.12 \% \mathrm{Cr}, 0.05 \% \mathrm{Sn}, 0.008 \% \mathrm{~N}, 0.0012 \% \mathrm{O}_{\mathrm{C}}$, ingot cross-section: $220 \times 1065 \mathrm{~mm}, V_{\mathrm{c}}=0.80$ $\mathbf{m} / \mathbf{m i n}, \boldsymbol{T}_{\text {odl. }}=\mathbf{1 5 1 2}^{\circ} \mathrm{C}$ )

a)

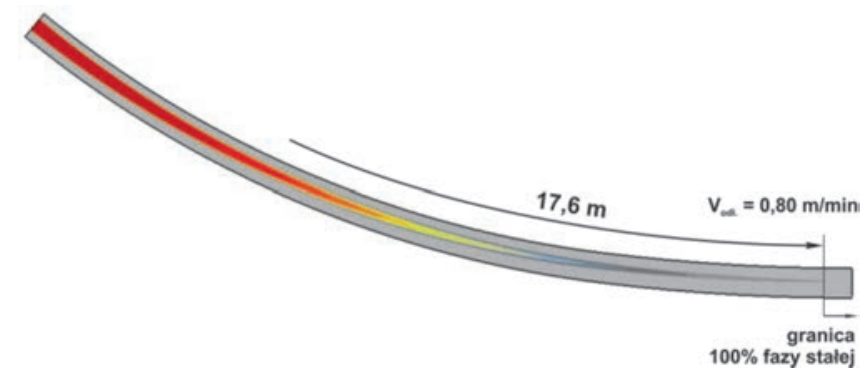

b)

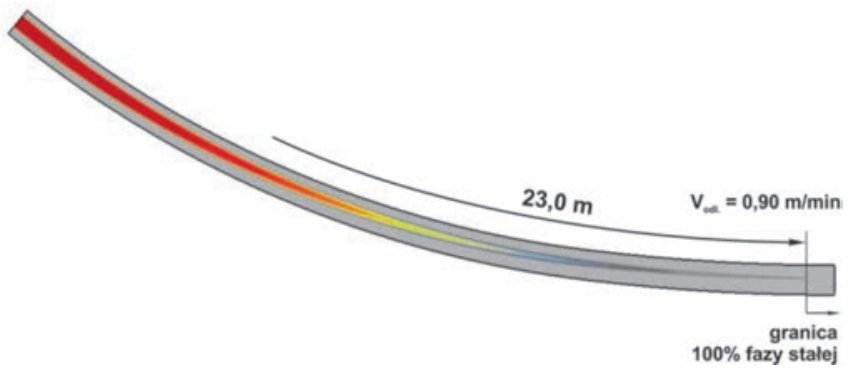

Rys. 3. Prognozowany zasięg fazy ciekłej w czasie odlewania stali: a) $\left.V_{c}=0,80 \mathrm{~m} / \mathrm{min}, \mathrm{b}\right) \mathrm{V}_{\mathrm{c}}=0,90 \mathrm{~m} / \mathrm{min}$ ( $\mathrm{skład}$ chemiczny stali: $0,048 \%$ C, $0,15 \%$ Mn, 3,20\% Si, 0,023\% P, 0,006\% S, 0,019\% Al, 0,12\% Cr, 0,05\% Sn, 0,008\% N, 0,0012\% C $_{\mathrm{C}}$, przekrój wlewka: $220 \times 1065$ mm, $T_{\text {odl. }}=\mathbf{1 5 1 2}^{\circ} \mathrm{C}$ )

Fig. 3. Forecast range of the liquid phase during steel casting: a) $V_{c}=0.80 \mathrm{~m} / \mathrm{min}, \mathrm{b}$ ) $\mathrm{V}_{\mathrm{c}}=0.90 \mathrm{~m} / \mathrm{min}$ (chemical composition of the steel: $0.048 \%$ C, 0.15\% Mn, 3.20\% Si, 0.023\% P, 0.006\% S, 0.019\% Al, 0.12\% Cr, 0.05\% Sn, 0.008\% N, 0.0012\% O $220 \times 1065 \mathrm{~mm}, T_{\text {odl. }}=1512^{\circ} \mathrm{C}$ ) 
chemicznym z planowanymi modyfikacjami w stosunku do obecnie wytwarzanej będzie mogła być odlewana w sposób ciągły na maszynie COS beneficjenta. Symulację przeprowadzono dla dwóch prędkości odlewania 0,8 i $0,9 \mathrm{~m} / \mathrm{min}$. W obu przypadkach prognozowany zasięg fazy ciekłej mieści się w długości metalurgicznej urządzenia, która wynosi $23,5 \mathrm{~m}$. Odlewanie z wyższą prędkością niż $0,9 \mathrm{~m} / \mathrm{min}$, przy założonych warunkach chłodzenia, nie jest wskazane $\mathrm{z}$ uwagi na możliwość przekroczenia długości metalurgicznej oraz ryzyko uzyskania na wyjściu z krystalizatora naskórka o zbyt małej grubości.

\subsubsection{Symulacje procesów segregacji pierwiastków podczas krzepnięcia stali transformatorowej z wykorzystaniem programu DICTRA}

Obliczenia przeprowadzone $\mathrm{z}$ wykorzystaniem programu DICTRA [8] dotyczyły symulacji procesu krzepnięcia w celu ustalenia podatności składników stali do segregacji międzydendrytycznej. Przed przystąpieniem do symulacji przeprowadzono równowagowe obliczenia za pomoca programu ThermoCalc v. 2017b. W obliczeniach przyjęto skład chemiczny stali podany w tabeli 2 .

Wyniki przeprowadzonych obliczeń przedstawiono na rys. 4. Na ich podstawie określono wartość następujących charakterystycznych temperatur dla warunków równowagi: - temperatura likwidus: $T_{\mathrm{L}}=1492,2^{\circ} \mathrm{C}$

- temperatura solidus: $T_{\mathrm{S}}=1444,8^{\circ} \mathrm{C}$

- przedział temperaturowy stabilności austenitu: 796,3: $1327,8^{\circ} \mathrm{C}$

- temperatura maksymalnej stabilności austenitu (udział austenitu $29,6 \%$ ): $1160^{\circ} \mathrm{C}$.

Obliczenia przeprowadzono dla szybkości chłodzenia stali wynoszącej 0,15 oraz $0,5^{\circ} \mathrm{C} / \mathrm{s}$ wyznaczonych na podstawie symulacji numerycznych z wykorzystaniem programu ProCast (Rys. 5). Z uwagi na porównywalny wynik symulacji dla tych szybkości chłodzenia, wyniki zaprezentowane zostaną dla jednej wartości szybkości $-0,15^{\circ} \mathrm{C} / \mathrm{s}$. Obliczenia rozpoczęto dla temperatury $1600^{\circ} \mathrm{C}$ i prowadzono do momentu,

Tabela 2. Skład chemiczny stali wykorzystany w obliczeniach, [\% mas.owe]

Table 2. Chemical composition of steel used in the calculations, [mass \%]

\begin{tabular}{|c|c|c|c|}
\hline $\mathbf{C}$ & $\mathbf{M n}$ & $\mathbf{S i}$ & $\mathbf{C r}$ \\
\hline 0,05 & 0,14 & 3,13 & 0,13 \\
\hline
\end{tabular}

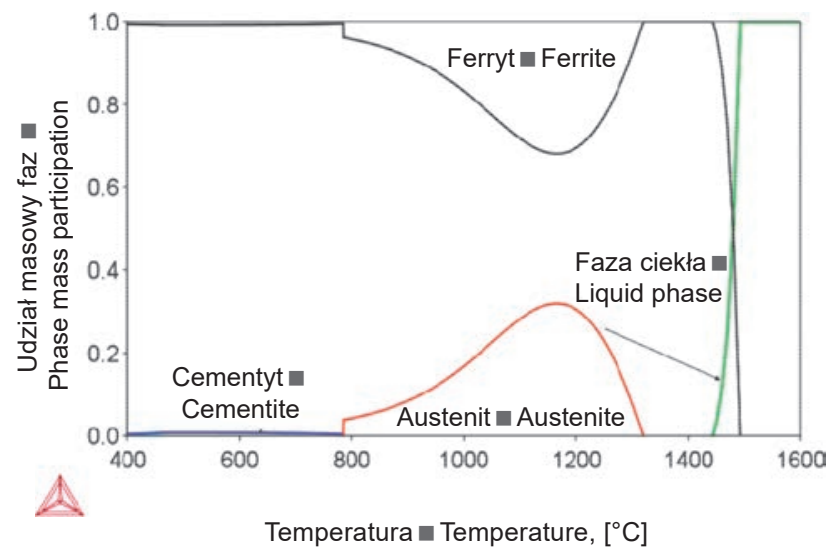

Rys. 4. Zmiany udziałów faz w funkcji temperatury dla warunków równowagowych

Fig. 4. Changes in the content of phases as a function of temperature for equilibrium conditions with the planned modifications in relation to the currently produced one will be able to be cast continuously on the beneficiary's CC machine. The simulation was carried out for two casting rates of 0.8 and $0.9 \mathrm{~m} / \mathrm{min}$. In both cases, the forecast range of the liquid phase is within the metallurgical length of the device, which is $23.5 \mathrm{~m}$. Casting at a rate higher than $0.9 \mathrm{~m} / \mathrm{min}$, under the assumed cooling conditions, is not recommended due to the possibility of exceeding the metallurgical length and the risk of obtaining, at the crystalliser outlet, a shroud of too small thickness.

\subsubsection{Simulations of element segregation processes during transformer steel solidification using the DICTRA program}

Calculations carried out using the DICTRA program [8] concerned simulation of the solidification process in order to determine the susceptibility of steel ingredients to interdendritic segregation. Before starting the simulation, equilibrium calculations were carried out using the ThermoCalc v. $2017 \mathrm{~b}$ program. The chemical composition given in Table 2 was used in the calculations.

The results of the calculations are shown in Fig. 4. The following characteristic temperatures were determined for equilibrium conditions based on them:

- liquidus temperature: $T_{\mathrm{L}}=1492.2^{\circ} \mathrm{C}$

- solidus temperature: $T_{\mathrm{S}}=1444.8^{\circ} \mathrm{C}$

- austenite stability temperature range: $796.3-1327.8^{\circ} \mathrm{C}$

- maximum austenite stability temperature (austenite content of $29.6 \%$ ): $1160^{\circ} \mathrm{C}$.

The calculations were carried out for the steel cooling rate of 0.15 and $0.5^{\circ} \mathrm{C} / \mathrm{s}$ determined on the basis of numerical simulations using the ProCast program (Fig. 5). Due to the comparable simulation result for these cooling rates, the results are presented for one rate value $-0.15^{\circ} \mathrm{C} / \mathrm{s}$. The calculations were started at $1600^{\circ} \mathrm{C}$ and were carried out until the temperature reached about $60^{\circ} \mathrm{C}$ below the solidus temperature, stable ferrite temperature, i.e. $-1380^{\circ} \mathrm{C}$.

Tabela 3. Temperatury stali po różnych czasach chłodzenia z szybkością $0,14^{\circ} \mathrm{C} / \mathrm{s}$

Table 3. Temperatures of steel after various cooling times at a rate of $0.14{ }^{\circ} \mathrm{C} / \mathrm{s}$

\begin{tabular}{|c|c|c|}
\hline $\begin{array}{c}\text { Czas chłodzenia } \\
\text { Cooling time } \\
{[\mathrm{s}]}\end{array}$ & $\begin{array}{c}\text { Temperatura } \\
\text { Temperature } \\
{\left[{ }^{\circ} \mathbf{C}\right]}\end{array}$ & $\begin{array}{c}\text { Stan układu/Skład fazowy } \\
\text { System condition/Phase } \\
\text { composition }\end{array}$ \\
\hline 1000 & 1460 & $\begin{array}{l}\text { Faza ciekła + ferryt delta } \\
\text { Liquid phase + delta ferrite }\end{array}$ \\
\hline 1800 & 1348 & Ferryt $\square$ Ferrite \\
\hline 2500 & 1250 & $\begin{array}{l}\text { Austenit }+ \text { ferryt } \\
\text { Austenite }+ \text { ferrite }\end{array}$ \\
\hline 3000 & 1180 & $\begin{array}{l}\text { Austenit + ferryt } \\
\text { Austenite + ferrite }\end{array}$ \\
\hline
\end{tabular}

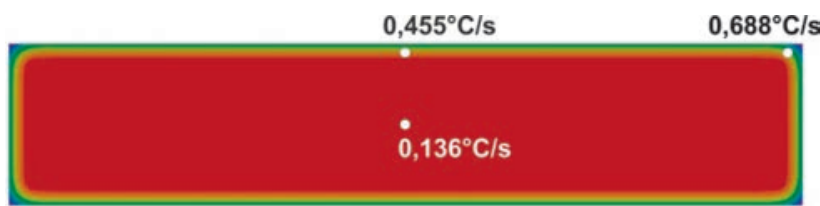

Rys. 5. Wartości szybkości chłodzenia stali w strefie chłodzenia wtórnego w procesie COS określone na podstawie symulacji przeprowadzonych z wykorzystaniem programu ProCast

Fig. 5. Steel cooling rate values in the secondary cooling zone in the CC process determined on the basis of simulations carried out using the ProCast program 
gdy temperatura osiagnęła wartość około $60^{\circ} \mathrm{C}$ poniżej temperatury solidus, temp. stabilnego ferrytu, czyli $1380^{\circ} \mathrm{C}$.

Temperatury stali po wskazanych czasach podano w tabeli 3.

Symulacje przeprowadzono dla wyjściowej temperatury stali wynoszącej $1600^{\circ} \mathrm{C}$. Wyniki symulacji zmian stężenia pierwiastków po różnych czasach krzepnięcia wzdłuż linii o długości $\chi / 2=100 \mu \mathrm{m}$ przedstawiono na rys. 6 .

Pierwszą fazą stałą powstającą w analizowanym układzie jest ferryt. Jej wzrost powoduje segregację składników stali do cieczy. W momencie zakrzepnięcia w układzie występuje tylko jedna faza - ferryt. Podczas chłodzenia w temperaturowym zakresie stabilności ferrytu następuje ujednorodnienie składu chemicznego w przestrzeniach międzydendrytycznych. Następnie, podczas dalszego chłodzenia, w temperaturze około $1327^{\circ} \mathrm{C}$, w układzie pojawia się austenit. Podczas wzrostu tej fazy atomy C, Cr i Mn segregują do niej, zaś Si segreguje do ferrytu. Przeprowadzone obliczenia pokazują, że współczynnik segregacji dla poszczególnych pierwiastków $\left(k=\mathrm{X}_{\mathrm{FCC}} / \mathrm{X}_{\mathrm{BCC}}\right)$ nie jest wysoki.
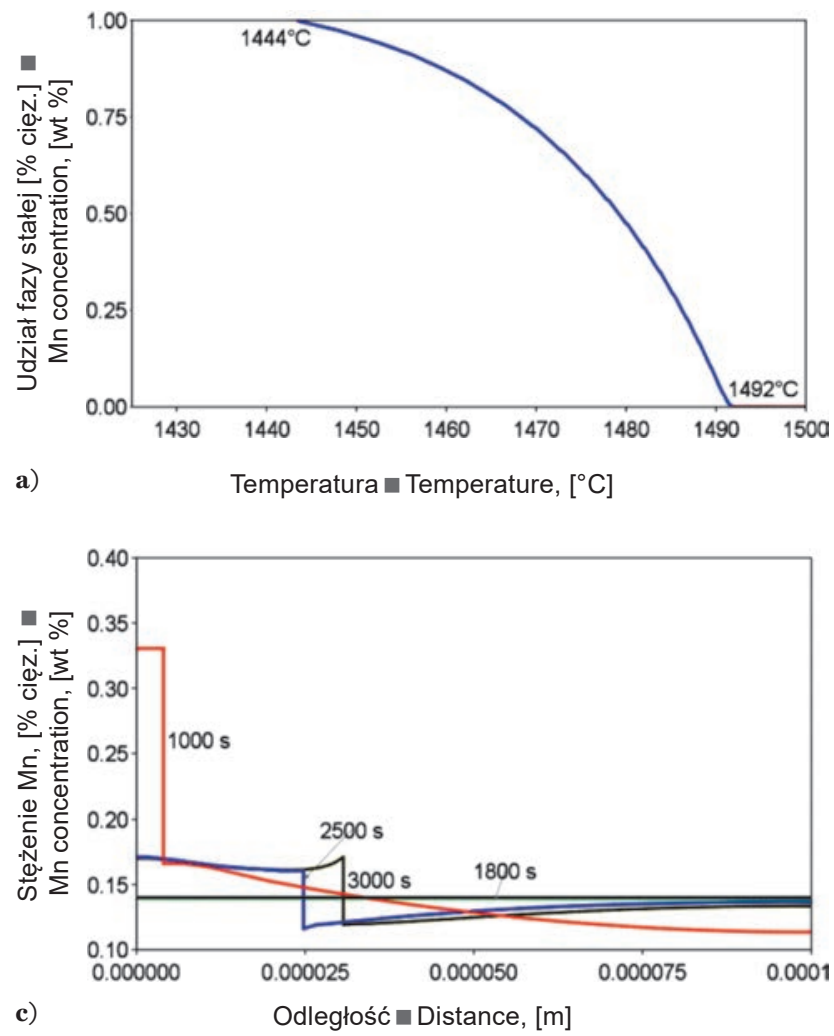

The temperatures of steels after the indicated times are given in Table 3.

The simulations were carried out for the initial temperature of steel of $1600^{\circ} \mathrm{C}$. The results of the simulations of changes in the concentration of elements after different solidification times along a line with the length of $\chi / 2=$ $100 \mu \mathrm{m}$ are presented in Fig. 6 .

The first phase forming in the analysed system is ferrite. Its increase results in the segregation of steel ingredients to liquid. There is only one phase - ferrite - in the system at the moment of solidification. When cooling in the ferrite temperature stability range, the chemical composition is homogenised in interdendritic spaces. Then, during further cooling, austenite is formed in the system at approx. $1327^{\circ} \mathrm{C}$. During the growth of this phase, $\mathrm{C}, \mathrm{Cr}$ and $\mathrm{Mn}$ atoms segregate into it, while $\mathrm{Si}$ segregates into ferrite. The calculations show that the segregation factor for individual elements $\left(k=\mathrm{X}_{\mathrm{FCC}} / \mathrm{X}_{\mathrm{BCC}}\right)$ is not high.
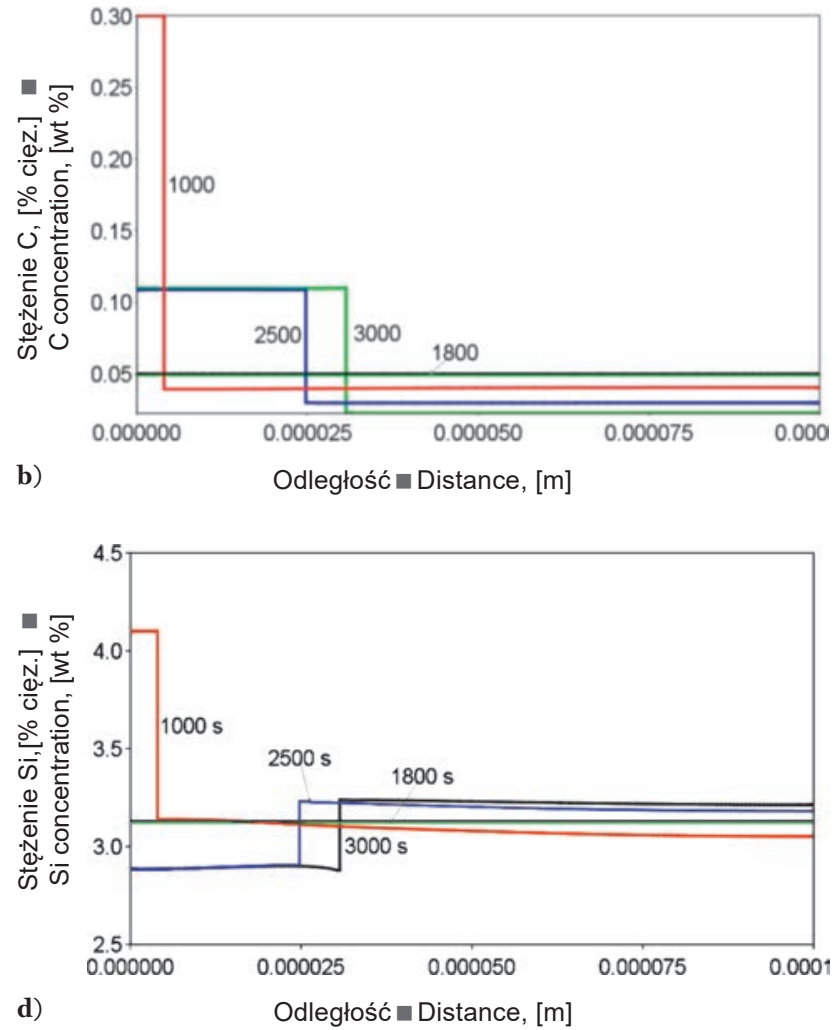

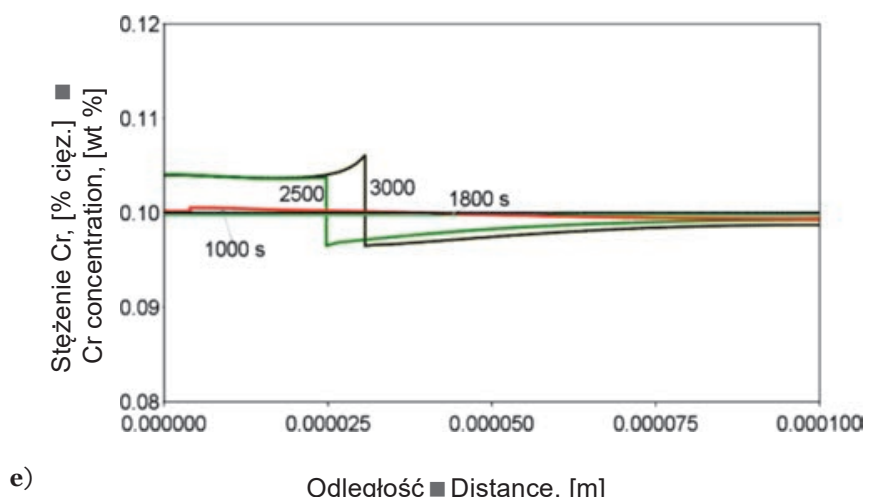

Rys. 6. Wyniki symulacji numerycznej segregacji pierwiastków podczas krzepnięcia stali transformatorowej dla szybkości chłodzenia $0,14^{\circ} \mathrm{C} / \mathrm{s}$ : a) udział fazy stałej, b) zmiany rozkładu $\mathrm{C}$, c) zmiany rozkładu $\mathrm{Mn}, \mathrm{d}$ ) zmiany rozkładu $\left.\mathrm{Si}, \mathrm{e}\right) \mathrm{zmiany} \mathrm{rozkładu} \mathrm{Cr}$

Fig. 6. Results of the numerical simulation of element segregation during the solidification of transformer steel for the cooling rate of $0.14^{\circ} \mathrm{C} / \mathrm{s}$ : a) solid phase content, b) changes in $\mathrm{C}$ distribution, c) changes in $\mathrm{Mn}$ distribution, d) changes in Si distribution, e) changes in Cr distribution 


\subsection{DOŚWIADCZALNE WYTOPY LABORATORYJNE}

$\mathrm{W}$ warunkach laboratoryjnych do wytworzenia materiału badawczego do badań właściwości technologicznych i badań materiałoznawczych wykorzystano próżniowy piec indukcyjny. Pierwsze wytopy badawcze wykonano przy użyciu pieca VIM Lab 30, który pozwala na uzyskanie wlewków o masie do $30 \mathrm{~kg}$, a następnie pieca VSG 100 wytapiającego do $100 \mathrm{~kg}$ ciekłej stali.

Stal odlewano do wlewnic żeliwnych z nadstawką uzyskując wlewki o masie $\sim 30 \mathrm{~kg}$ i $~ 100 \mathrm{~kg}$ o przekroju kw. 160/140 mm (Rys. 7) lub do tak zwanego krystalizatora, będącego wlewnica miedziana (kw. $100 \mathrm{~mm}$ ) o chłodzonych woda ściankach (w pewnym stopniu symulującą wlewek odlewany metodą ciągłą).

Wykonano 13 wytopów (Tab. 4) różniących się składem chemicznym (bez i z udziałem $\mathrm{Sn}, \mathrm{z}$ różną zawartością azotu) zmieniając technologię, w tym sposób wprowadzania azotu. Uzyskany materiał posłużył do przeprowadzenia badań materiałoznawczych w stanie po odlaniu, a w przypadku części wytopów także w stanie po walcowaniu na gorąco. $\mathrm{Z}$ materiału pobrano próbki do analizy wtrąceń niemetalicznych, wyznaczenia charakterystyk wysokotemperaturowych i symulacji procesów metalurgicznych za pomocą symulatora Gleeble 3800.

Jednym z istotnych wniosków z przeprowadzonych wytopów jest konieczność doboru wsadu celem ograniczenia ilości tytanu tworzącego niekorzystne węgliki lub węglikoazotki, a szczególnie pierwotne TiN.

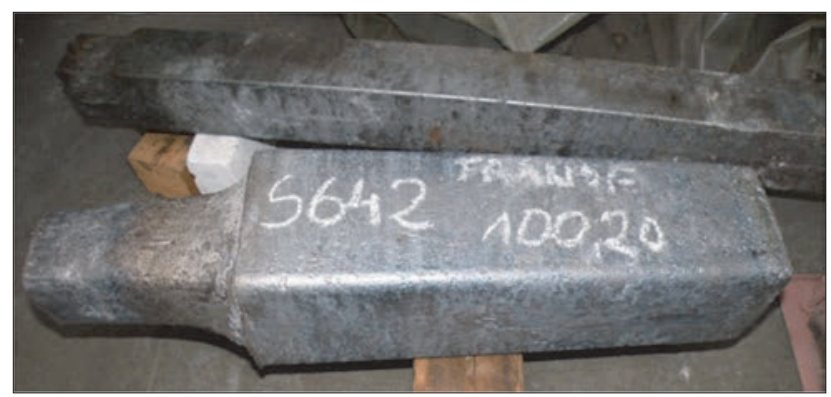

\subsection{EXPERIMENTAL LABORATORY MELTS}

In laboratory conditions, a vacuum induction furnace was used to produce research material for testing technological properties and material studies. The first test melts were obtained using a VIM Lab 30 furnace, which allows obtaining ingots that weigh up to $30 \mathrm{~kg}$, and then a VSG 100 furnace melting up to $100 \mathrm{~kg}$ of liquid steel.

The steel was cast into iron ingot moulds with extension, obtaining ingots weighing $\sim 30 \mathrm{~kg}$ and $\sim 100 \mathrm{~kg}$ with a square cross section of $160 / 140 \mathrm{~mm}$ (Fig. 7), or to the "crystalliser", which is a copper ingot mould $(100 \mathrm{~mm})$ with water-cooled walls (somewhat simulating a continuously cast ingot).

13 melts were made (Table 4) differing in chemical composition (without and with Sn, with different nitrogen content) changing the technology, including the method of nitrogen introduction. The obtained material was used to conduct material research after casting, and in the case of some melts also after hot rolling. Samples were collected from the material for the analysis of non-metallic inclusions, determination of high-temperature characteristics and simulation of metallurgical processes using a Gleeble 3800 simulator.

One of the important conclusions from the conducted melts is the need to select the charge to reduce the amount of titanium forming unfavourable carbides or carbonitrides, especially primary TiN.

Tabela 4. Składy chemiczne wytopów laboratoryjnych stali elektrotechnicznej

Table 4. Chemical compositions of laboratory melts of electrical steel

\begin{tabular}{|c|c|c|c|c|c|c|c|c|c|c|c|c|}
\hline \multirow{2}{*}{$\begin{array}{l}\text { Lp. } \\
\text { No. }\end{array}$} & \multirow{2}{*}{ Wytop $\square$ Melt } & \multicolumn{11}{|c|}{ Skład chemiczny, [\% mas.] = Chemical composition, [mass \%] } \\
\hline & & $\mathbf{C}$ & Mn & Si & $\mathbf{P}$ & $\mathbf{S}$ & Al & $\mathbf{C r}$ & Sn & $\mathbf{N}$ & $\mathbf{O}_{\mathrm{C}}$ & Ti \\
\hline 1 & $\begin{array}{l}\text { Wariant } 1 \text { wg KM1 } \\
\text { Variant } 1 \text { per KM1 }\end{array}$ & $\begin{array}{c}0,030 \div \\
0,065\end{array}$ & $\begin{array}{c}0,08 \div \\
0,25\end{array}$ & $\begin{array}{l}3,10 \div \\
3,30\end{array}$ & $\begin{array}{l}0,018 \div \\
0,028\end{array}$ & $\begin{array}{c}0,004 \div \\
0,008\end{array}$ & $\begin{array}{l}0,010 \div \\
0,030\end{array}$ & $\begin{array}{c}0,06 \div \\
0,20\end{array}$ & $\begin{array}{c}0,02 \div \\
0,07\end{array}$ & $\begin{array}{l}0,006 \div \\
0,010\end{array}$ & $\begin{array}{c}\max . \\
0,0012\end{array}$ & - \\
\hline 2 & Nr 139 & 0,05 & 0,14 & 3,13 & 0,023 & 0,004 & 0,029 & 0,099 & 0,052 & 0,0045 & 0,0016 & n.b. \\
\hline 3 & $\mathrm{~N} 140$ & 0,05 & 0,19 & 3,16 & 0,023 & 0,004 & 0,025 & 0,14 & 0,046 & 0,005 & 0,0012 & n.b. \\
\hline 4 & $\mathrm{~N} 141$ & 0,049 & 0,16 & 3,12 & 0,023 & 0,004 & 0,032 & 0,19 & 0,047 & 0,0046 & 0,0006 & n.b. \\
\hline 5 & $\mathrm{~N} 142$ & 0,042 & 0,17 & 3,07 & 0,023 & 0,004 & 0,011 & 0,11 & 0,049 & 0,023 & 0,0016 & n.b. \\
\hline 6 & $\mathrm{~N} 143$ & 0,046 & 0,16 & 3,20 & 0,025 & 0,004 & 0,01 & 0,11 & 0,047 & 0,012 & 0,0010 & n.b. \\
\hline 7 & $\mathrm{~N} 157$ & 0,042 & 0,16 & 3,14 & 0,026 & 0,004 & 0,009 & 0,14 & 0,050 & 0,0080 & 0,0011 & 0,0020 \\
\hline 8 & $\mathrm{~S} 645$ & 0,049 & 0,17 & 3,25 & 0,025 & 0,004 & 0,015 & 0,10 & 0,052 & 0,0090 & 0,0006 & 0,0035 \\
\hline 9 & S 667 & 0,05 & 0,11 & 3,17 & 0,027 & 0,007 & 0,028 & 0,10 & 0,054 & 0,0072 & 0,0006 & $<0,001$ \\
\hline 10 & $\begin{array}{l}\text { Wariant } 2 \text { wg KM1 } \\
\text { Variant } 2 \text { per KM1 }\end{array}$ & $\begin{array}{c}0,030 \div \\
0,065\end{array}$ & $\begin{array}{c}0,08 \div \\
0,25\end{array}$ & $\begin{array}{l}3,10 \div \\
3,30\end{array}$ & $\begin{array}{l}0,018 \div \\
0,028\end{array}$ & $\begin{array}{c}0,004 \div 1 \\
0,008\end{array}$ & $\begin{array}{l}0,010 \div \\
0,030\end{array}$ & $\begin{array}{c}0,08 \div \\
0,20\end{array}$ & - & $\begin{array}{c}0,007 \div \\
0,009\end{array}$ & $\begin{array}{c}\max . \\
0,0012\end{array}$ & - \\
\hline 11 & N 137 & 0,047 & 0,27 & 3,39 & 0,027 & 0,004 & 0,024 & 0,12 & - & 0,0059 & 0,0015 & n.b. \\
\hline 12 & N 144 & 0,05 & 0,15 & 3,18 & 0,025 & 0,004 & 0,020 & 0,11 & - & 0,0117 & 0,0010 & n.b. \\
\hline 13 & N 156 & 0,047 & 0,16 & 3,12 & 0,024 & 0,004 & 0,016 & 0,12 & - & 0,0090 & 0,0006 & 0,0018 \\
\hline 14 & S 642 & 0,05 & 0,21 & 3,16 & 0,027 & 0,006 & 0,022 & 0,19 & - & 0,0080 & 0,0007 & 0,005 \\
\hline 15 & S 666 & 0,04 & 0,10 & 3,22 & 0,020 & 0,005 & 0,027 & 0,10 & - & 0,0077 & 0,0006 & $<0,001$ \\
\hline
\end{tabular}

n.b. - nie badano $\square$ not tested

Rys. 7. Wlewki stali: na pierwszym planie $100 \mathrm{~kg}$ wlewek kw. $160 / 140 \mathrm{~mm}$; na drugim planie wlewek $\mathrm{z}$ wlewnicy miedzianej chłodzonej wodą

Fig. 7. Steel ingots: in the foreground a $100 \mathrm{~kg} 160 / 140 \mathrm{~mm}$ square ingot; in the background an ingot from a water-cooled copper ingot mould 


\subsection{WALCOWANIE NA GORĄCO Z WYKORZYSTANIEM LINII SYMULACYJNEJ}

Walcowanie płaskowników ze stali elektrotechnicznych zrealizowano w linii LPS składającej się z pieca grzewczego, jednoklatkowej walcarki duo nawrotnej o średnicy walców $550 \mathrm{~mm}$ i długości beczki $700 \mathrm{~mm}$ i pieca termosu do obróbki cieplnej bezpośrednio po zakończeniu walcowania. Wsad do walcowania stanowiły pręty kwadratowe uzyskane metodą kucia wlewków odlanych do wlewnicy żeliwnej kwadrat 160/140 mm i wlewki kwadratowe odlane do krystalizatora o przekroju kw. $100 \mathrm{~mm}$. Parametry nagrzewania stali dobrano w oparciu o skład chemiczny oraz prognozowane właściwości plastyczne $\mathrm{w}$ zakresie temperatury przeróbki plastycznej na gorąco, uwzględniając wymagania odnośnie do właściwości wyrobu końcowego. Do wyznaczenia średniego nacisku jednostkowego, jaki wywiera pasmo na walce, zastosowano metodę Zjuzina. W obliczeniach uwzględniono wpływ stanu naprężenia i szerokości pasma w zależności od współczynnika kształtu kotliny walcowania. Do obliczenia wartości naprężenia uplastyczniającego wykorzystano metodę Hensla i Spittla. Na podstawie obliczonych wielkości parametrów technologicznych opracowano program walcowania kęsów/wlewków na płaskowniki o założonej grubości nominalnej $3 \mathrm{~mm}$.

Program walcowania obją:

- walcowanie wstępne w 8 przepustach na płaskowniki o wymiarach: $26,5 \times 150 \times 2510 \mathrm{~mm}$ i $19 \times 136 \times 2610 \mathrm{~mm}$

- w drugim etapie walcowanie płaskowników w 4 przepustach na pasma o grubości około $12 \mathrm{~mm}$ i długości w zakresie 1660 $\div 1680 \mathrm{~mm}$ oraz o długości w zakresie od $1200 \mathrm{~mm}$ do $1270 \mathrm{~mm}$ (w zależności od wsadu)

- w trzecim etapie walcowanie wsadu w 4 przepustach na pasma o grubości około 4,7 mm (Rys. 8)

- walcowanie końcowe w 3 przepustach na wyroby gotowe o grubości finalnej około $3 \mathrm{~mm}$.

Pasma bezpośrednio po walcowaniu transportowano do pieca-termosu nagrzanego do temperatury $600^{\circ} \mathrm{C}$, po czym studzono z piecem do temperatury otoczenia.

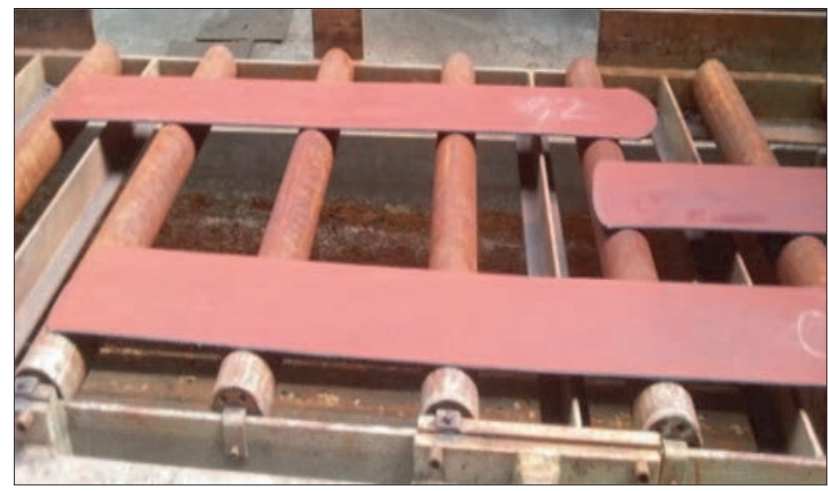

\subsection{BADANIA MATERIAEOZNAWCZE}

$\mathrm{Na}$ materiałach z wytopów laboratoryjnych i wyprzedzająco wykonanych wytopów przemysłowych, w stanie po odlaniu i po przeróbce plastycznej na gorąco, przeprowadzono badania materiałoznawcze, które objęły:

- analizę jakościową i ilościową wtrąceń niemetalicznych,

- opracowanie charakterystyk wysokotemperaturowych z wykorzystaniem symulatora Gleeble.

\subsubsection{Badania wtrąceń niemetalicznych}

Badania wtrąceń niemetalicznych objęły analizę jakościową i ilościową w materiale z wytopów laboratoryjnych w sta-

\subsection{HOT ROLLING USING A SIMULATION LINE}

The rolling of flat bars made of electrical steel was carried out in the LPS line consisting of a heating furnace, a single-frame reverse duo rolling mill with a roll diameter of 550 $\mathrm{mm}$ and a barrel length of $700 \mathrm{~mm}$, and a thermocontainer furnace for heat treatment immediately after rolling. The rolling charge consisted of square bars obtained by forging ingots cast into a 160/140 mm square cast iron ingot mould and square ingots cast into a crystalliser with a square section of $100 \mathrm{~mm}$. The steel heating parameters were selected based on the chemical composition and forecast plastic properties in the range of hot plastic working temperature, taking into account the requirements for the properties of the final product. The Zjuzin method was applied to determine the average unit pressure exerted by the strip on the rollers. The calculations took into account the influence of stress state and strip width depending on the rolling hollow shape factor. The Hensel-Spittel method was used to calculate the value of flow stress. Based the calculated technological parameters, a billet/ingot rolling programme was developed for flat bars with the assumed nominal thickness of $3 \mathrm{~mm}$.

The rolling programme included:

- pre-rolling in 8 passes into flat bars with the following dimensions: $26.5 \times 150 \times 2510 \mathrm{~mm}$ and $19 \times 136 \times 2610 \mathrm{~mm}$

- in the second stage, the flat bars were rolled in 4 passes into approx. $12 \mathrm{~mm}$ thick strips with lengths in the range of $1660-1680 \mathrm{~mm}$ and lengths in the range from 1200 $\mathrm{mm}$ to $1270 \mathrm{~mm}$ (depending on the charge)

- in the third stage, the charge was rolled in 4 passes into approx. $4.7 \mathrm{~mm}$ thick strips (Fig. 8)

- final rolling in 3 passes into finished products with a final thickness of approx. $3 \mathrm{~mm}$.

Immediately after rolling, the strips were transported to a thermocontainer furnace heated to $600^{\circ} \mathrm{C}$ and then cooled with the furnace to ambient temperature.

Rys. 8. Pasma o grubości około 4,7 mm

Fig. 8. Strips with a thickness of approx. $4.7 \mathrm{~mm}$

\subsection{MATERIAL STUDIES}

Material studies, which included the following, were carried out for the materials from laboratory melts and premade industrial melts after casting and after hot working:

- qualitative and quantitative analysis of non-metallic inclusions

- development of high temperature characteristics using a Gleeble simulator.

\subsubsection{Studies on non-metallic inclusions}

Tests of non-metallic inclusions included qualitative and quantitative analysis in the material from laboratory melts 
nie po odlaniu (wlewek), po przeróbce plastycznej (walcowanie na goracco), wyprzedzających wytopów przemysłowych na próbkach po kolejnych etapach przeróbki plastycznej.

Z próbek wykonano wzdłużne zgłady metalograficzne. Analizę wtrąceń niemetalicznych wykonano na zgładach $\mathrm{w}$ stanie nietrawionym. Badania przeprowadzono za pomoca elektronowego mikroskopu skaningowego Inspect $\mathrm{F}$ z wykorzystaniem detektora EDS do mikroanalizy składu chemicznego.

W próbkach zidentyfikowano następujące wtrącenia niemetaliczne:

- tlenko-siarczki złożone np. z $\mathrm{Al}_{2} \mathrm{O}_{3}-\mathrm{MgO}^{-\mathrm{TiO}_{2}}-(\mathrm{Mn}, \mathrm{Ca}) \mathrm{S}$

- drobne konglomeraty złożone z azotków AlN i TiN oraz siarczków MnS

- siarczki manganu MnS lub (FeMn)S.

Najliczniej w próbkach pobieranych z wlewków występowały drobne wtrącenia niemetaliczne o średnicy równoważnej poniżej $1 \mu \mathrm{m}$. Przykładowe wtrącenia niemetaliczne zidentyfikowane w wytopie N141 przedstawiono na rys. 9.

Ocenę ilościową wtrąceń niemetalicznych wykonano z wykorzystaniem oprogramowania do analizy obrazu Met-Ilo [8]. Każdorazowo badania wykonano na powierzchni wynoszącej 1,4 $\mathrm{mm}^{2}$. Przykładowe uśrednione wyniki analizy ilościowej wtrąceń niemetalicznych (WN) przedstawiono w tabeli 5 . after casting (ingots), after plastic working (hot rolling), pre-emptive industrial melts on samples after subsequent stages of plastic working.

Longitudinal microsections were obtained from the samples. The analysis of non-metallic inclusions was carried out on non-etched microsections. The tests were carried out using an Inspect F scanning electron microscope with an EDS detector for chemical composition microanalysis.

The following non-metallic inclusions were identified in the samples:

- sulphide-oxides composed of e.g. $\mathrm{Al}_{2} \mathrm{O}_{3}-\mathrm{MgO}-\mathrm{TiO}_{2}-$ (Mn, Ca)S

- fine conglomerates composed of AlN and TiN nitrides and MnS sulphides

- MnS or (FeMn)S manganese sulphides.

Most often in samples taken from the ingots, there were small non-metallic inclusions with an equivalent diameter below $1 \mu \mathrm{m}$. Examples of non-metallic inclusions identified in melt N141 are shown in Fig. 9.

The quantitative assessment of non-metallic inclusions was performed using the Met-Ilo image analysis software [8]. Each test was carried out on a surface area of $1.4 \mathrm{~mm}^{2}$. Examples of average results of quantitative analysis of non-metallic inclusions (WN) are presented in Table 5 .
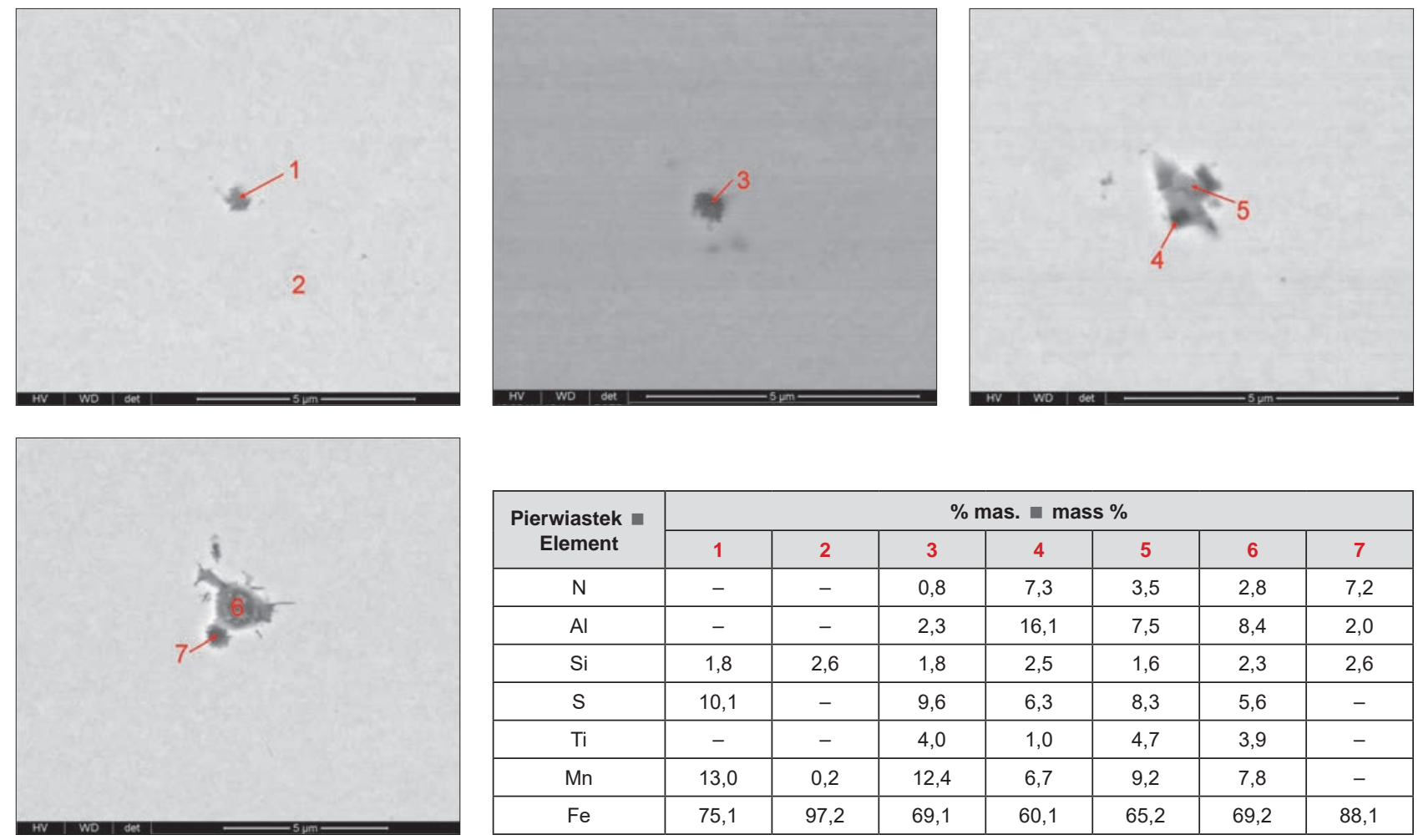

\begin{tabular}{|c|c|c|c|c|c|c|c|}
\hline \multirow{2}{*}{$\begin{array}{c}\text { Pierwiastek } \\
\text { Element }\end{array}$} & \multicolumn{7}{|c|}{ \% mas. mass \% } \\
\cline { 2 - 8 } & $\mathbf{1}$ & $\mathbf{2}$ & $\mathbf{3}$ & $\mathbf{4}$ & $\mathbf{5}$ & $\mathbf{6}$ & $\mathbf{7}$ \\
\hline $\mathrm{N}$ & - & - & 0,8 & 7,3 & 3,5 & 2,8 & 7,2 \\
\hline $\mathrm{Al}$ & - & - & 2,3 & 16,1 & 7,5 & 8,4 & 2,0 \\
\hline $\mathrm{Si}$ & 1,8 & 2,6 & 1,8 & 2,5 & 1,6 & 2,3 & 2,6 \\
\hline $\mathrm{S}$ & 10,1 & - & 9,6 & 6,3 & 8,3 & 5,6 & - \\
\hline $\mathrm{Ti}$ & - & - & 4,0 & 1,0 & 4,7 & 3,9 & - \\
\hline $\mathrm{Mn}$ & 13,0 & 0,2 & 12,4 & 6,7 & 9,2 & 7,8 & - \\
\hline $\mathrm{Fe}$ & 75,1 & 97,2 & 69,1 & 60,1 & 65,2 & 69,2 & 88,1 \\
\hline
\end{tabular}

Rys. 9. Przykładowe wtrącenia niemetaliczne w próbce z wytopu nr N141 wraz z wynikami ich mikroanalizy składu chemicznego Fig. 9. Examples of non-metallic inclusions in the sample from melt N141 together with the results of their chemical composition microanalysis

\subsection{BADANIA Z WYKORZYSTANIEM SYMULATORA GLEEBLE 3800}

W ramach badań charakterystyk wysokotemperaturowych stali wyznaczono (Tab. 6):

- temperaturę zerowej wytrzymałości - NST

- temperaturę utraty plastyczności - NDT

- temperaturę odzyskania plastyczności - DRT

- temperaturę odzyskania wytrzymałości - SRT.

\subsection{STUDIES USING A GLEEBLE 3800 SIMULATOR}

The following were determined as part of testing the high-temperature characteristics of steel (Table 6):

- nil-strength temperature - NST

- nil-ductility temperature - NDT

- ductility recovery temperature - DRT

- strength recovery temperature - SRT. 
Tabela 5. Przykładowe uśrednione wyniki analizy ilościowej wtrąceń niemetalicznych Table 5. Examples of average quantitative analysis results for non-metallic inclusions

\begin{tabular}{|c|c|c|c|}
\hline $\begin{array}{c}\text { Wartość/cecha } \\
\text { Value/feature }\end{array}$ & $\begin{array}{c}\text { Udział powierzchniowy wtrąceń } \\
\text { niemetalicznych w danym } \\
\text { polu } \text { w Surface fraction of non- } \\
\text { metallic inclusions in a given area } \\
{[\%]}\end{array}$ & $\begin{array}{c}\text { Pole powierzchni zajęte przez } \\
\text { wtrącenia niemetaliczne dla danego } \\
\text { pola } \text { Surface area occupied by } \\
\text { non-metallic inclusions for a given } \\
\text { area }\left[\mu^{2}\right]\end{array}$ & $\begin{array}{c}\text { Średnia średnica równoważna } \\
\text { wtrąceń niemetalicznych dla } \\
\text { danego pola } \square \text { Average equivalent } \\
\text { diameter of non-metallic inclusions } \\
\text { for a given area }[\mu \mathrm{m}]\end{array}$ \\
\hline \multicolumn{4}{|c|}{ Próbki z wytopu 140 (stan lany - wlewek) $\square$ Samples from melt 140 (cast state - ingot) } \\
\hline $\begin{array}{l}\text { Wartość średnia } \\
\text { Average value }\end{array}$ & 0,04 & 2,27 & 1,46 \\
\hline $\begin{array}{l}\text { Odchylenie } \\
\text { standardowe } \\
\text { Standard deviation }\end{array}$ & 0,02 & 4,37 & 0,88 \\
\hline \multicolumn{4}{|c|}{ Próbki z wytopu N141 (stan lany - wlewek) Samples from melt 141 (cast state - ingot) } \\
\hline $\begin{array}{l}\text { Wartość średnia } \\
\text { Average value }\end{array}$ & 0,03 & 0,44 & 0,64 \\
\hline $\begin{array}{l}\text { Odchylenie } \\
\text { standardowe } \\
\text { Standard deviation }\end{array}$ & 0,03 & 1,13 & 0,39 \\
\hline \multicolumn{4}{|c|}{ Próbki z wytopu S642 (stan gorącowalcowany - blacha) Samples from melt S642 (hot-rolled state - sheet) } \\
\hline $\begin{array}{l}\text { Wartość średnia } \\
\text { Average value }\end{array}$ & 0,110 & 0,258 & 0,530 \\
\hline $\begin{array}{l}\text { Odchylenie } \\
\text { standardowe } \square \\
\text { Standard deviation }\end{array}$ & 0,036 & 0,365 & 0,214 \\
\hline
\end{tabular}

Tabela 6. Wyniki badania charakterystyk wysokotemperaturowych stali z wytopów laboratoryjnych

Table 6. Results of high-temperature characteristics study for the steel from laboratory melts

\begin{tabular}{|c|c|c|c|c|}
\hline \multirow{2}{*}{ Wytop $=$ Melt } & \multicolumn{4}{|c|}{ Temperatura $=$ Temperature, $\left[{ }^{\circ} \mathbf{C}\right]$} \\
\hline & NST & NDT & DRT & SRT \\
\hline $\mathrm{N} 140$ & 1405 & & & \\
\hline N141 & & 1400 & 1390 & 1441 \\
\hline $\mathrm{N} 144$ & & 1410 & 1395 & 1449 \\
\hline
\end{tabular}

Uzyskane na podstawie ww. badań wyniki stanowią tak zwaną „mapę odlewania ciągłego”. Na podstawie analizy uzyskanych wyników stwierdzono, że badana stal (w analizowanym przedziale składów chemicznych) charakteryzuje się bardzo wąskim przedziałem temperaturowym utraty oraz nawrotu plastyczności. Różnice wartości poszczególnych wyznaczonych temperatur charakterystycznych nie przekraczają $10^{\circ} \mathrm{C}$. Oznacza to, że ciągłe odlewanie stali należy prowadzić w ściśle kontrolowanych warunkach temperatury, prędkości odlewania i wtórnego chłodzenia pasma.

\subsection{SYMULACJA PROCESU WALCOWANIA NA GORĄCO}

Zakres realizowanych badań obejmował przeprowadzenie symulacji fizycznej procesu walcowania blach transformatorowych na gorąco za pomoca symulatora Gleeble 3800. W symulacjach zastosowano próbki o wymiarach $15 \times 20 \times 35 \mathrm{~mm}$ ze stali $\mathrm{S} 645$ i S642. Schemat przeprowadzonych badań przedstawiono na rys. 10. Wariant „01” symulacji obejmował pełny cykl produkcyjny i kończył sie chłodzeniem do temperatury zwijania w krąg $\left(547^{\circ} \mathrm{C}\right)$ i wytrzymaniem w czasie 1 godziny w tej temperaturze i dalszym wolnym chłodzeniem do temperatury otoczenia z szybkością $0,5^{\circ} \mathrm{C} / \mathrm{s}$ (Rys. 12). Pozostałe warianty kończyły się intensywnym chłodzeniem wodą po kolejnych odkształceniach.

Strukturę próbek ze stali S645 po przeprowadzonych symulacjach przedstawiono na rys. 11 .

$\mathrm{Na}$ podstawie obrazów mikrostruktury można wnosić, że w trakcie procesu walcowania, w strukturze stali rośnie
The results obtained on the basis of the above-mentioned tests constitute the "continuous casting map". Based on the analysis of the obtained results, it was found that the tested steel (in the analysed range of chemical compositions) is characterised by a very narrow temperature range of loss and recurrence of plasticity. The differences in the values of individual determined characteristic temperatures do not exceed $10^{\circ} \mathrm{C}$. This means that continuous steel casting should be carried out under strictly controlled conditions of temperature, casting rate and secondary cooling of the strip.

\subsection{HOT ROLLING PROCESS SIMULATION}

The scope of performed research included conducting a physical simulation of the hot rolling process of transformer sheets using a Gleeble 3800 simulator. $15 \times 20 \times 35 \mathrm{~mm}$ samples from steel S645 and S642 were used in the simulations. A diagram of the conducted studies is presented in Fig. 10. Variant "01" of the simulation covered a full production cycle and ended with cooling to coiling temperature $\left(547^{\circ} \mathrm{C}\right)$ and holding for 1 hour at this temperature and further slow cooling to ambient temperature at a rate of $0.5^{\circ} \mathrm{C} / \mathrm{s}$ (Fig. 12). Other variants ended in intensive cooling with water after subsequent deformations.

The structure of S645 steel samples after simulations is shown in Fig. 11.

Based on microstructure images, it can be concluded that the ferrite content in the steel structure increases during the rolling process. Both ferrite and austenite are recrystallised after deformation, which results in fragmentation of the 


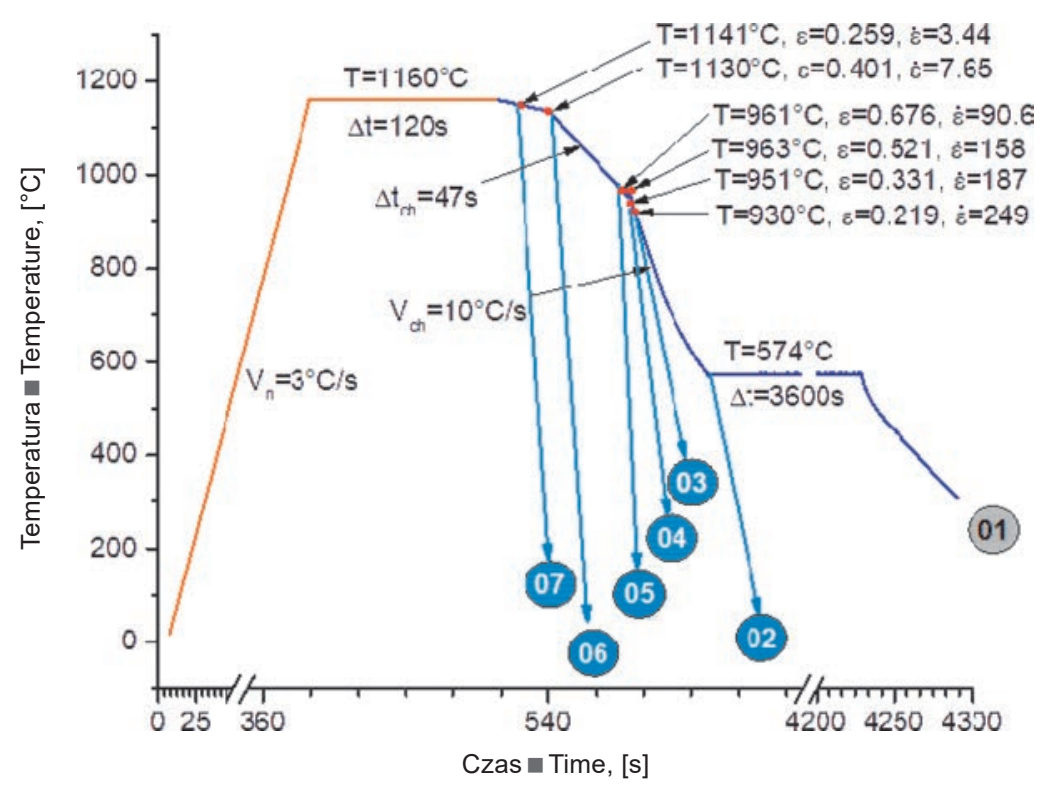

Rys. 10. Parametry procesu walcowania blach transformatorowych na gorąco za pomocą symulatora Gleeble 3800 Fig. 10. Parameters of the hot rolling process of transformer sheets using a Gleeble 3800 simulator
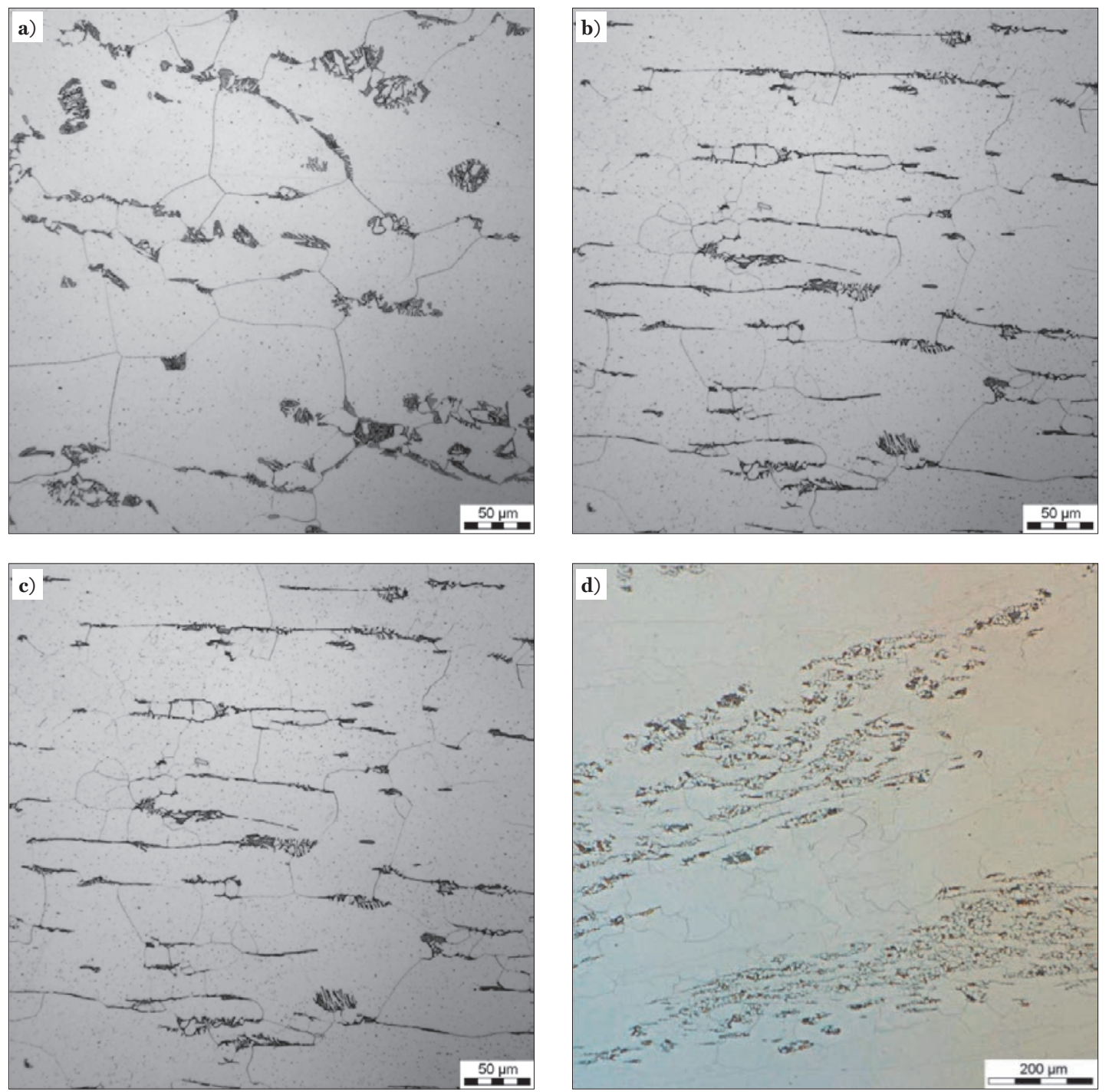

Rys. 11. Struktura próbek (pow. X 277) po kolejnych etapach symulacji procesu walcowania za pomocą symulatora Gleeble 380o, oznaczenie próbek zgodnie z rys. 10: a) 07, b) 06, c) 05, d) 04. Mikroskop świetlny

Fig. 11. Structure of samples (magn. X 277) after subsequent stages of the rolling process simulation using a Gleeble 3800 simulator, determination of the samples in accordance with Fig. 10: a) 07, b) 06, c) 05, d) 04. Light microscope 

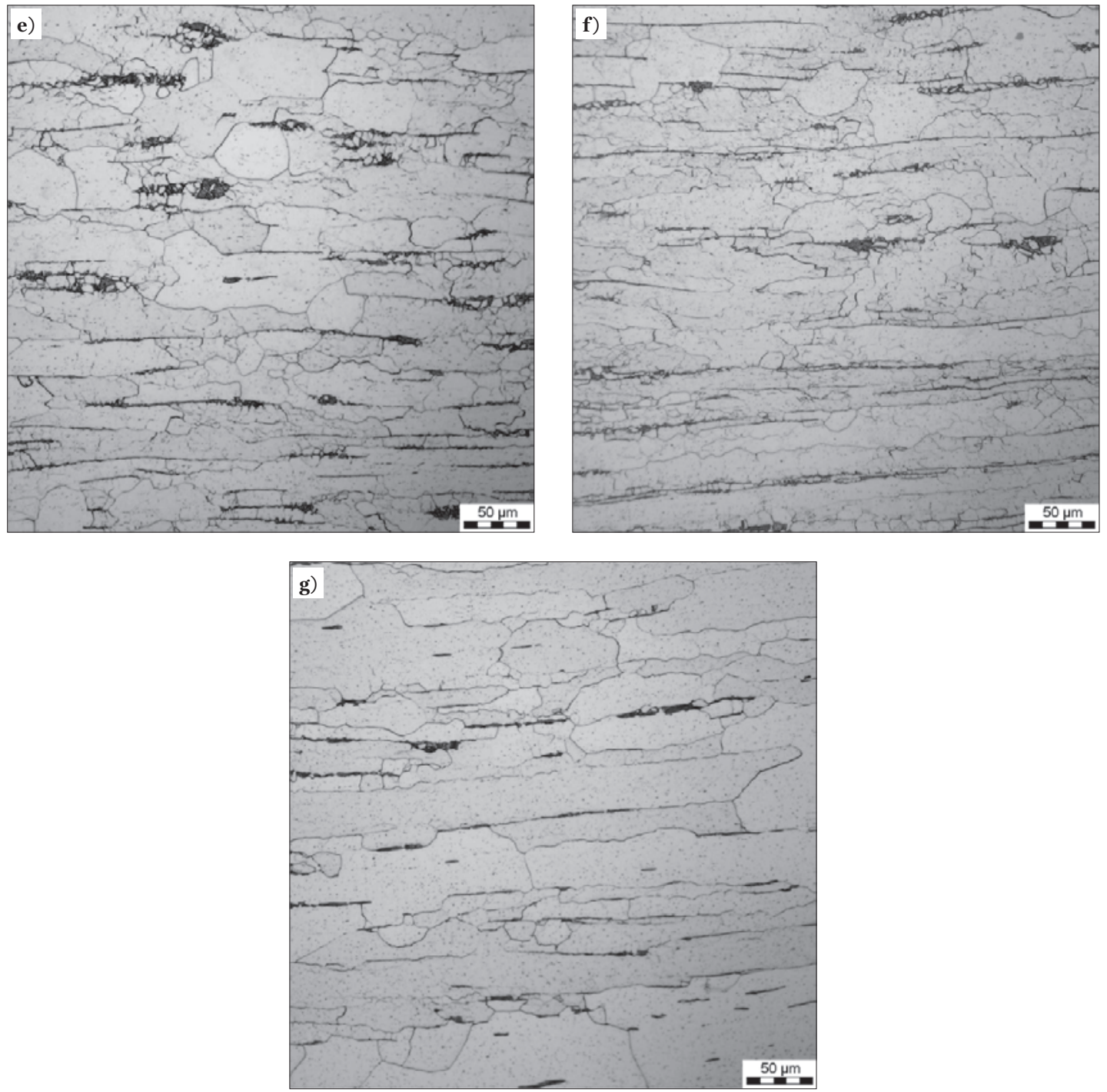

Rys. 11 cd. Struktura próbek (pow. ×277) po kolejnych etapach symulacji procesu walcowania za pomocą symulatora Gleeble 3800, oznaczenie próbek zgodnie z rys. 10: e) 03, f) 02, g) 01. Mikroskop świetlny

Fig. 11 cont. Structure of samples (magn. $\times 277$ ) after subsequent stages of the rolling process simulation using a Gleeble 3800 simulator, determination of the samples in accordance with Fig. 10: e) 03, f) 02, g) 01. Light microscope

udział ferrytu. Zarówno ferryt, jak i austenit podlegają rekrystalizacji po odkształceniu, co powoduje rozdrobnienie struktury stali. Jednak, podczas wolnego chłodzenia symulującego chłodzenie blachy w kręgu, część ziaren ferrytu rozrasta się do dużych rozmiarów. Średnia średnica równoważna największych ziarn ferrytu mieści się w przedziale $120 \div 270 \mu \mathrm{m}$.

Identyfikacje składników struktury próbek po odkształceniu w Gleeble przeprowadzono stosując również metodę skaningowej mikroskopii elektronowej. Wyniki tych badań uzyskane na próbkach z wytopu S645 przestawiono na rys. 12-18. Z badań tych wynika, że w strukturze próbek chłodzonych wodą po kolejnych symulacjach (próbki 07-03 wg rys. 10) występuje ferryt, martenzyt i niewielka ilość austenitu (Rys. 12-16). Z kolei w strukturze próbki chłodzonej do temperatury zwijania w krąg oraz po chłodzeniu symulującym chłodzenie naturalne kręgu (próbki 02 i 01 wg rys. 10) występuje ferryt i perlit (Rys. 17 i 18). Martenzyt i perlit w strukturze próbek powstał w wyniku przemiany austenitu wzbogaconego w węgiel. Zarys obszarów, w których występują te składniki struktury, odzwierciedla kształt austenitu przed przemianami fazowymi. Na zdjęciach struktury widoczne są drobne ziarna ferrytu, które jako pierwsze steel structure. However, during slow cooling simulating coil sheet cooling, some ferrite grains grow to large sizes. The average equivalent diameter of the largest ferrite grains is in the range of $120-270 \mu \mathrm{m}$.

The identification of sample structure components after deformation in Gleeble was also carried out using scanning electron microscopy. The results of these tests obtained for samples from the S645 melt are shown in Figs. 12-18. These studies show that there is ferrite, martensite and a small amount of austenite (Fig. 12-16) in the structure of water-cooled samples after subsequent simulations (samples 07-03 according to Fig. 10). There are ferrite and pearlite (Figs. 17 and 18) in the structure of the sample cooled to coiling temperature and after cooling simulating the natural cooling of the coil (samples 02 and 01 according to Fig. 10). Martensite and pearlite in the sample structure was formed as a result of the transformation of carbon-enriched austenite. The outline of the areas in which these structural components are present reflects the shape of austenite before phase transitions. The structure images show fine grains of ferrite, which were the first to form as a result of austenite disintegration. The shape of these areas is strongly elongated after the last deformation, which is related to the strong 

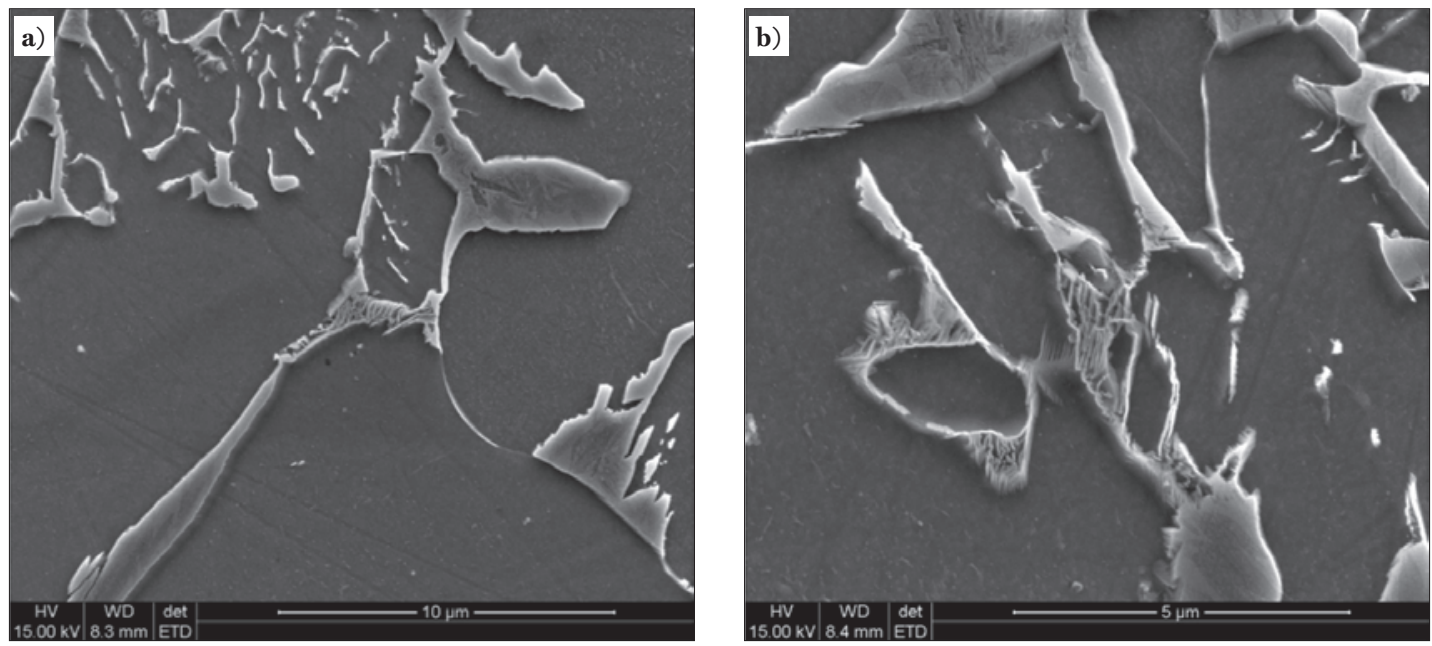

Rys. 12. Struktura otrzymana w wyniku symulacji procesu walcowania na symulatorze Gleeble 3800, próbka nr 07 zgodnie z rys. 10: (a) i (b) różne obszary i różne powiększenia. FEG_SEM

Fig. 12. Structure obtained as a result of the rolling process simulation using a Gleeble 3800 simulator, sample No. 07 according to Fig. 10 : (a) and (b) various areas and various magnifications. FEG_SEM
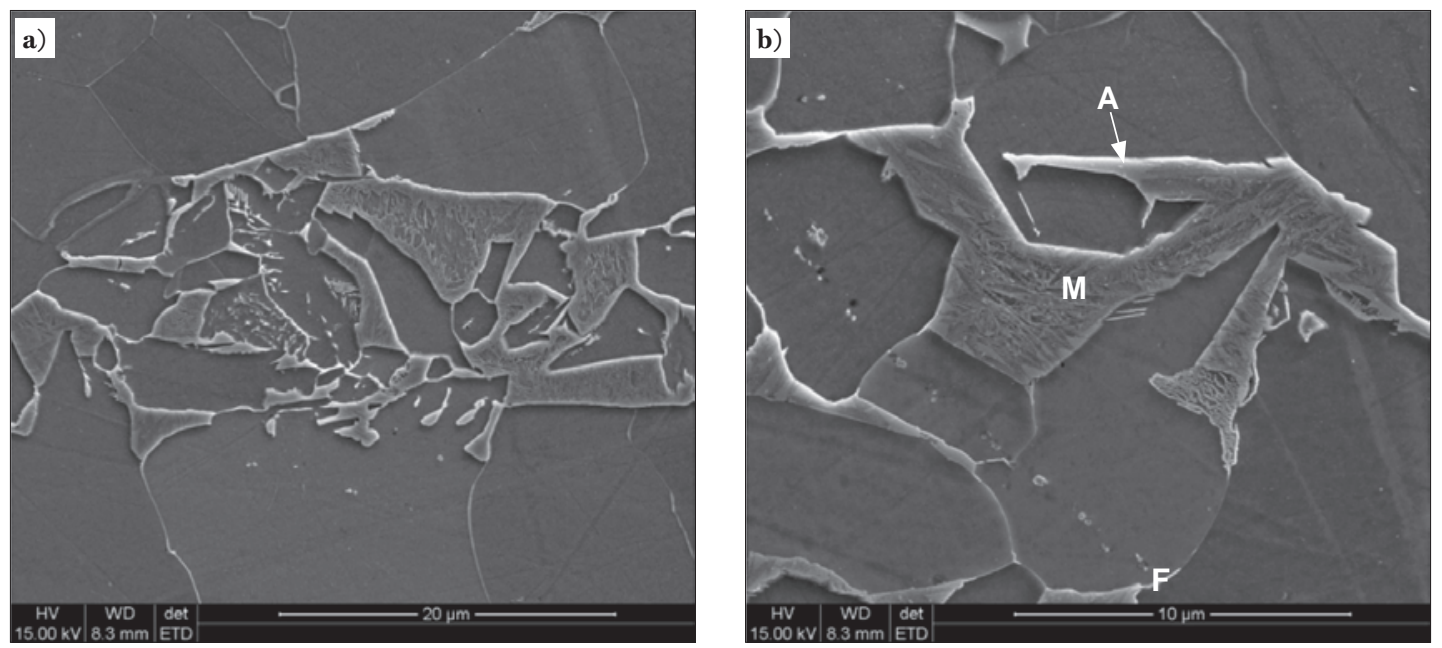

Rys. 13. Struktura otrzymana w wyniku symulacji procesu walcowania na symulatorze Gleeble 380o, próbka nr 06 zgodnie z rys. 10 : (a) i (b) różne obszary i różne powiększenia; F - ferryt, A - austenit, M - martenzyt. FEG_SEM

Fig. 13. Structure obtained as a result of the rolling process simulation using a Gleeble 3800 simulator, sample No. 06 according to Fig. 10 : (a) and (b) various areas and various magnifications; $\mathbf{F}$ - ferrite, $\mathbf{A}$ - austenite, $M$ - martensite. FEG_SEM
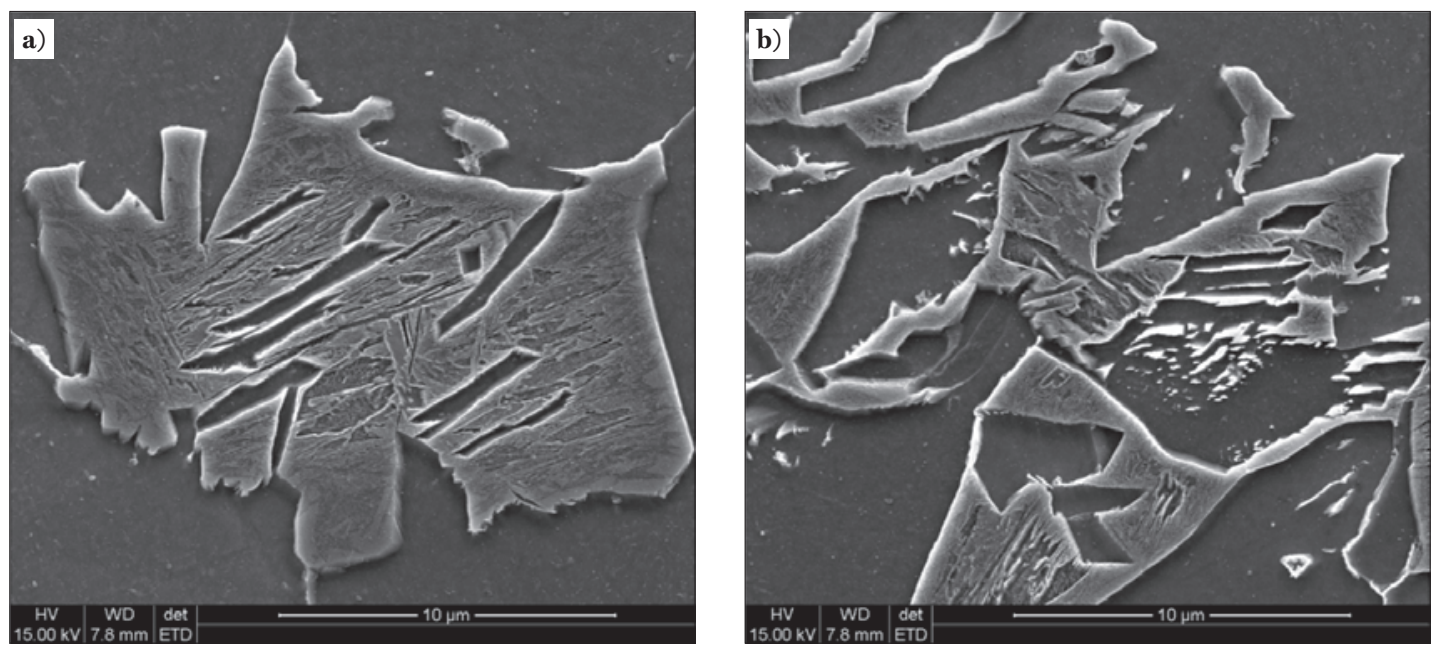

Rys. 14. Struktura otrzymana w wyniku symulacji procesu walcowania na symulatorze Gleeble 3800, próbka nr 05 zgodnie z rys. 10 : (a) i (b) różne obszary. FEG_SEM

Fig. 14. Structure obtained as a result of the rolling process simulation using a Gleeble 3800 simulator, sample No. 05 according to Fig. 10: (a) and (b) various areas. FEG_SEM 

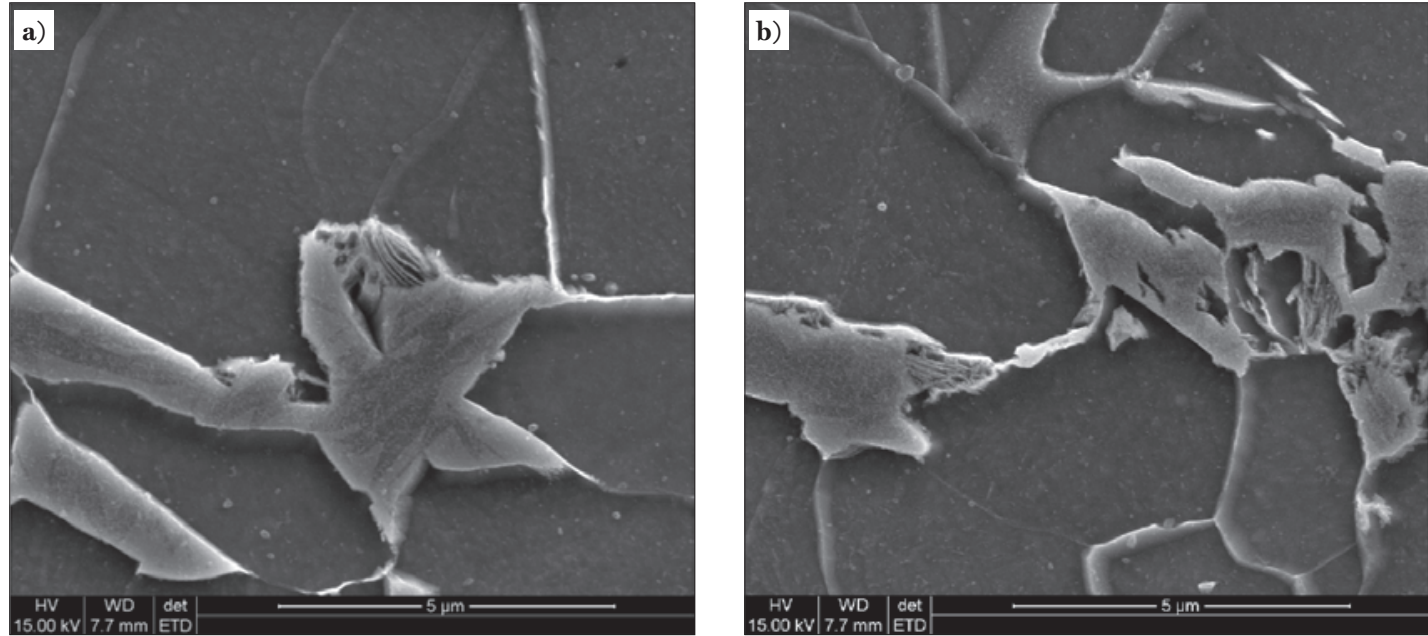

Rys. 15. Struktura otrzymana w wyniku symulacji procesu walcowania na symulatorze Gleeble 3800, próbka nr 04 zgodnie z rys. 10: (a) i (b) różne obszary. FEG_SEM

Fig. 15. Structure obtained as a result of the rolling process simulation using a Gleeble 3800 simulator, sample No. 04 according to Fig. 10: (a) and (b) various areas. FEG_SEM
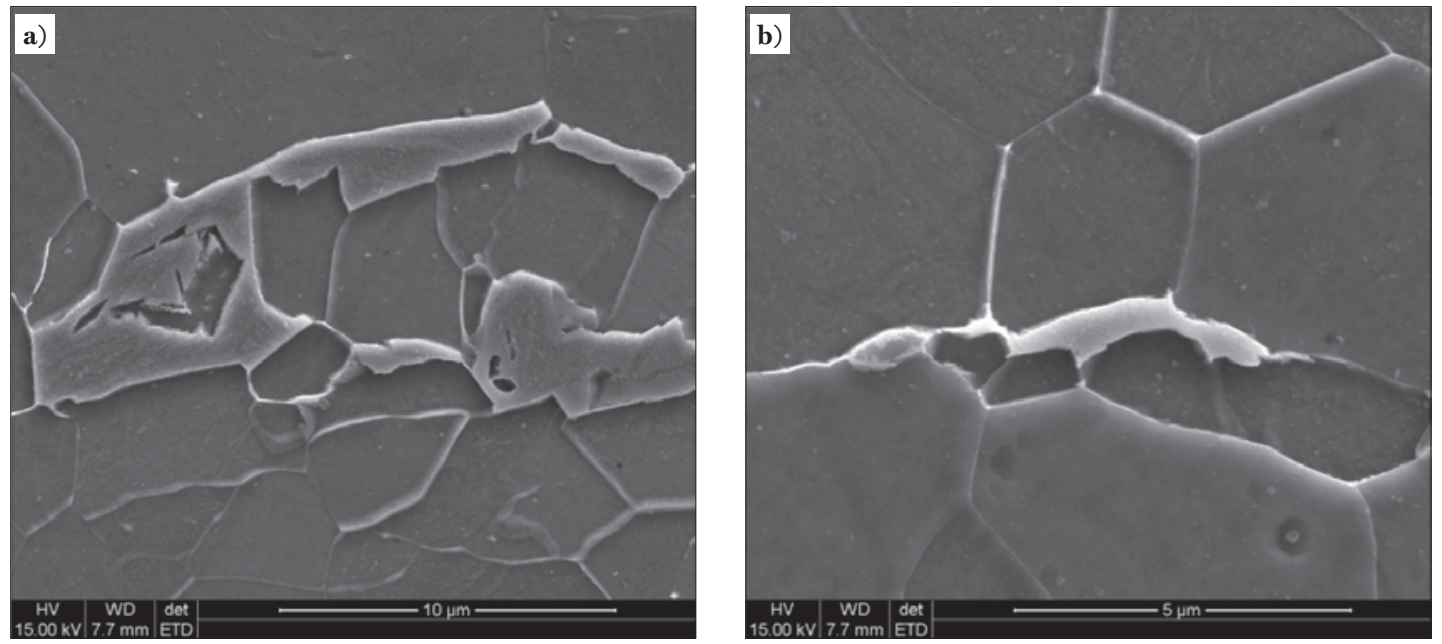

Rys. 16. Struktura otrzymana w wyniku symulacji procesu walcowania na symulatorze Gleeble 380o, próbka nr 03 zgodnie z rys. 10 : (a) i (b) różne obszary i różne powiększenia. FEG_SEM

Fig. 16. Structure obtained as a result of the rolling process simulation using a Gleeble 3800 simulator, sample No. 03 according to Fig. 10: (a) and (b) various areas and various magnifications. FEG_SEM
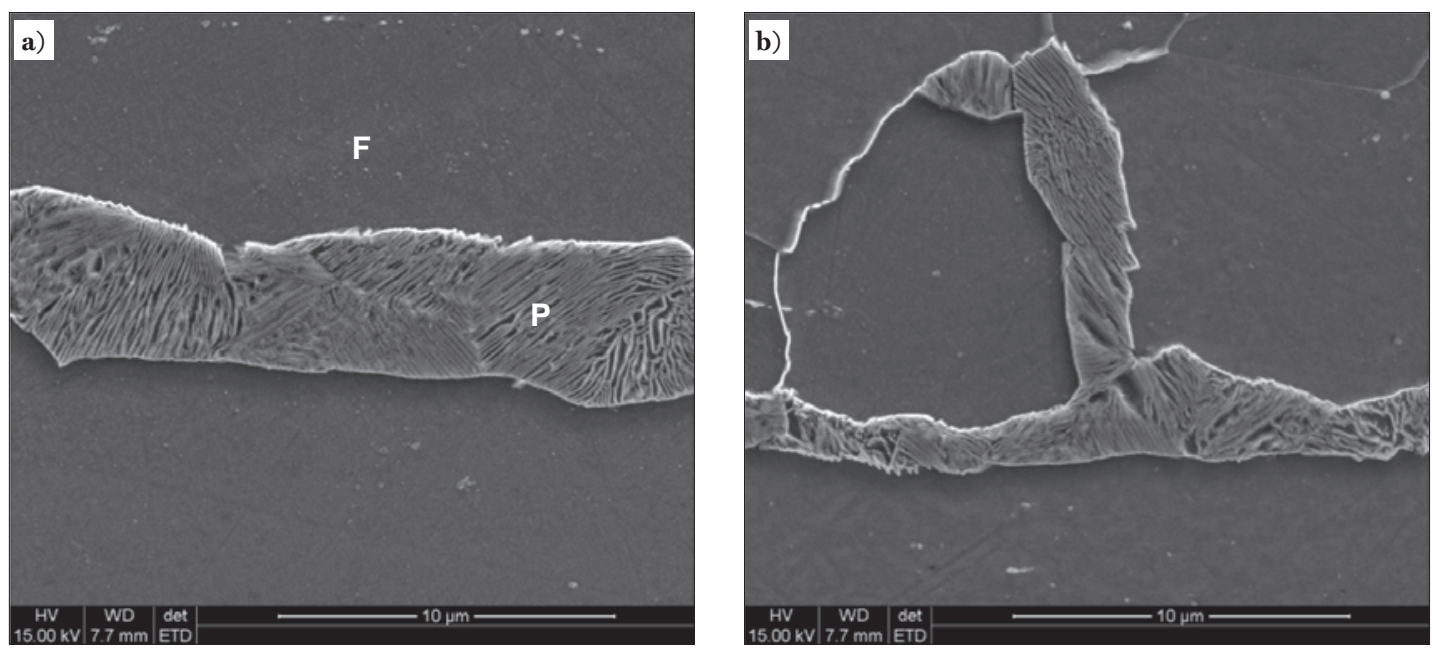

Rys. 17. Struktura otrzymana w wyniku symulacji procesu walcowania na symulatorze Gleeble 3800, próbka nr 02 zgodnie z rys. 10 : (a) i (b) różne obszary; $\mathbf{F}$ - ferryt, $\mathbf{P}$ - perlit. FEG_SEM

Fig. 17. Structure obtained as a result of the rolling process simulation using a Gleeble 3800 simulator, sample No. 02 according to Fig. 10: (a) and (b) various areas; $\mathbf{F}$ - ferrite, $\mathbf{P}$ - pearlite. FEG_SEM 

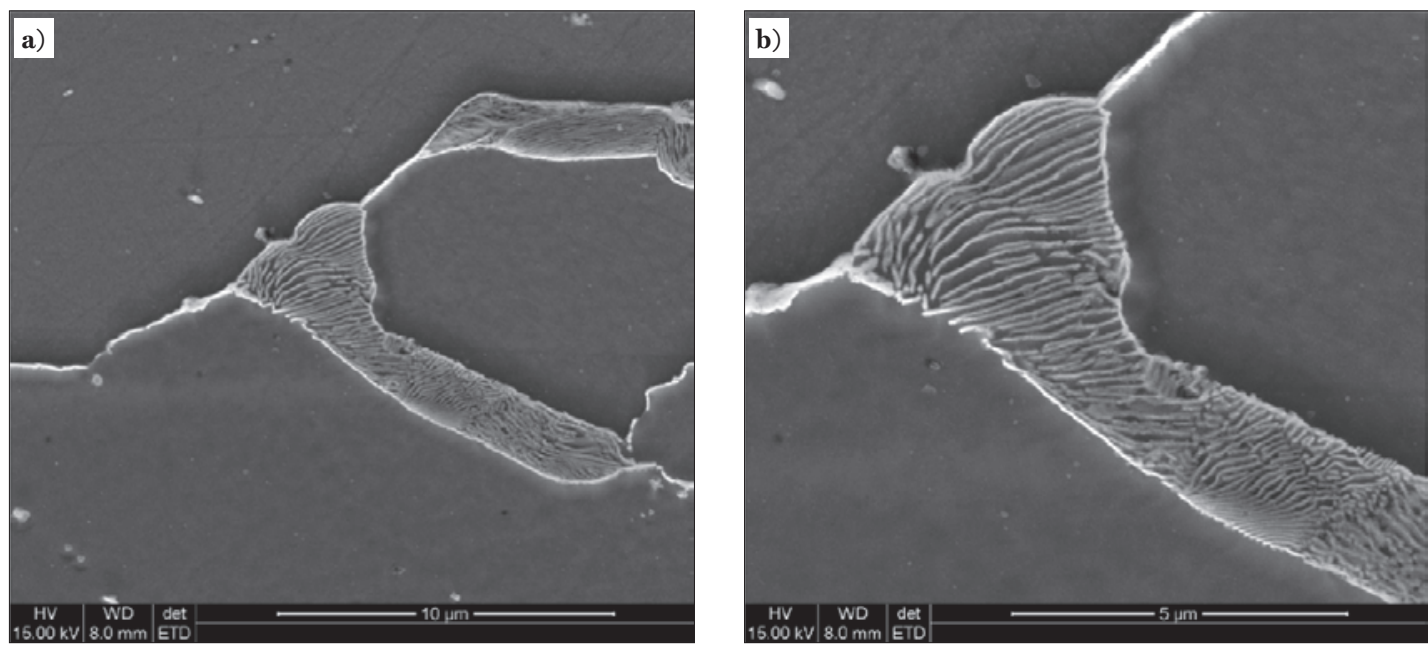

Rys. 18. Struktura otrzymana w wyniku symulacji procesu walcowania na symulatorze Gleeble 3800, próbka nr o1 zgodnie z rys. 10: a)-f) różne obszary i różne powiększenia. FEG_SEM

Fig. 18. Structure obtained as a result of the rolling process simulation using a Gleeble 3800 simulator, sample No. 01 according to Fig. 10: a)-f) various areas and various magnifications. FEG_SEM

utworzyły się w wyniku rozpadu austenitu. Kształt tych obszarów jest silnie wydłużony po ostatnim odkształceniu, co ma związek z silnym odkształceniem struktury oraz spowolniniem procesów jej odbudowy w miarę obniżania temperatury odkształcenia plastycznego.

W prowadzonych badaniach stwierdzono zbliżony przebieg zmian strukturalnych w różnych wytopach stali transformatorowych, co również znajduje odzwierciedlenie w krzywych naprężenie - odkształcenie zarejestrowanych podczas prowadzonych symulacji (Rys. 19). deformation of the structure and the slowdown of its reconstruction processes as the plastic deformation temperature decreases.

In the conducted studies, a similar course of structural changes was observed in various transformer steel melts, which is also reflected in the stress-strain curves registered during simulations (Fig. 19).

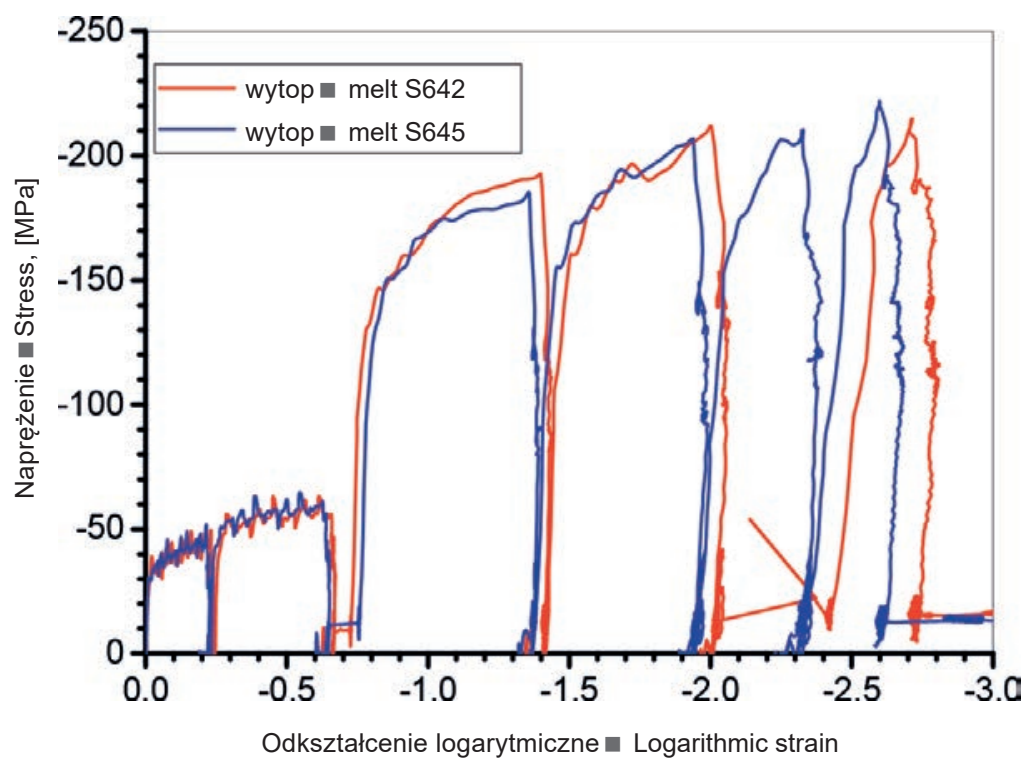

Rys. 19. Porównanie krzywych naprężenie - odkształcenie w przeprowadzonych symulacjach procesu walcowania blach dla próbek ze stali S645 i S642. Pełny cykl symulacji - wariant 01 na rys. 10

Fig. 19. Comparison of stress-strain curves in simulations of the sheet rolling process for samples from steel S645 and S642. Full simulation cycle - variant 01 in Fig. 10

\section{PODSUMOWANIE}

W ramach pracy wykonano symulacje numeryczne następujących procesów wytwarzania stali transformatorowej: - krzepnięcia oraz wydzielania wtrąceń niemetalicznych i faz międzymetalicznych decydujących o właściwościach

\section{SUMMARY}

As part of the study, numerical simulations of the following transformer steel production processes were performed: - solidification and precipitation of non-metallic inclusions and intermetallic phases that determine the properties of 
stali w funkcji poziomu tlenu całkowitego i pierwiastków wchodzących w skład tych wydzieleń, w tym: azotu, glinu, chromu i siarki oraz cyny i fosforu

- ciągłego odlewania celem określenia parametrów procesu, a także mikrosegregacji w krzepnącym wlewku ciągłym.

Symulacje fizyczne objęły: wytopy stali w próżniowym piecu indukcyjnym, walcowanie na goraco oraz wyznaczenie charakterystyk wysokotemperaturowych stali stanowiących tak zwaną „mapę odlewania ciągłego” - wyznaczenie przedziału temperaturowego utraty oraz nawrotu plastyczności.

Wykonane symulacje i zrealizowany program badań wytopów laboratoryjnych:

- potwierdziły możliwość uzyskania pożądanych wydzieleń AlN przy założonych kładach chemicznych stali z uwzględnieniem zawartości tlenu całkowitego na poziomie $10 \div 12 \mathrm{ppm}$

- umożliwiły uzyskanie materiału o wyznaczonych parametrach (składzie chemicznym, poziomie odtlenienia i udziale powierzchniowym wtrąceń niemetalicznych max. 0,05\%) do badań materiałoznawczych.

Uzyskane wyniki badań laboratoryjnych zostaną wykorzystane do opracowania doświadczalnej technologii wytapiania, odlewania i walcowania stali elektrotechnicznej nowej generacji w warunkach przemysłowych, a także do określenia wymagań techniczno-technologicznych instalacji demonstracyjnej do próżniowej obróbki stali ciekłej.

Publikacja zostata opracowana w ramach projektu nr POIR.01.01.01-00-0238/17 pt. „Innowacyjna stal wysokokrzemowa z regulowana niska zawartościa zanieczyszczeń $i$ wtraceń niemetalicznych o kontrolowanej morfologii oraz odporiednim poziomie inhibitora AlN z przeznaczeniem na roysokojakościowe blachy transformatorowe" wspótfinansowanego przez Narodowe Centrum Badań i Rozwoju, realizowanego przez ArcelorMittal Poland S.A. Oddziat w Krakowie. Podwykonawca kluczowych prac dla projektu jest Sieć Badawcza Eukasiewicz - Instytut Metalurgii Żelaza im. Stanistawa Staszica w Gliwicach.
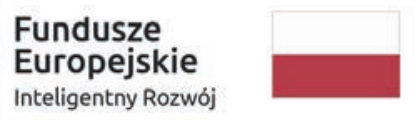

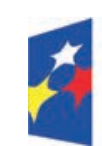

Inteligentny $f$

\section{Rzeczpospolita Polska}

steel as a function of the levels of total oxygen and elements included in these precipitates, including: nitrogen, aluminium, chromium and sulphur, as well as tin and phosphorus

- continuous casting to determine the process parameters as well as micro-segregation in the solidifying continuous ingot.

Physical simulations included: steel melting in a vacuum induction furnace, hot rolling and determination of high-temperature characteristics of the steel constituting the "continuous casting map" - determination of the temperature range for loss and recurrence of plasticity.

Performed simulations and testing programme for laboratory melts:

- confirmed the possibility of obtaining the desired AlN precipitates, with the assumed chemical compositions of steel taking into account the total oxygen content at the level of 10-12 ppm

- enabled obtaining material with determined parameters (chemical composition, deoxidation level and surface fraction of non-metallic inclusions max. $0.05 \%$ ) for material research.

The obtained results of laboratory tests will be used to develop experimental technology for melting, casting and rolling of new-generation electrical steel in industrial conditions, as well as to determine the technical and technological requirements of the demonstration installation for vacuum treatment of liquid steel.

The publication was prepared as part of project No. POIR.01.01.01-00-0238/17 "Innovative high-silicon steel with controlled low content of non-metallic impurities and inclusions with controlled morphology and an appropriate level of AlN inhibitor for high-quality transformer sheets" co-financed by the National Centre for Research and Development, implemented by ArcelorMittal Poland S.A. Unit in Krakóre. Eukasiewicz Research Network-Stanistaw Staszic Institute of Ferrous Metallurgy in Gliwice is the subcontractor of the studies for the project.

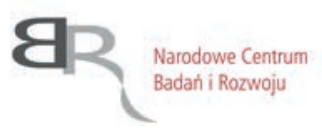
Unia Europejska Europejski Fundusz Rozwoju Regionalnego

\section{LITERATURA — REFERENCES}

[1] T. Takamiya, K. Hanazawa, T. Suzuki. Recent Development of Grain - Oriented Electrical Steel in JFE Steel. JFE Technical Report, 2016 (21), s. 3-6.

[2] N. Morito, M. Komatsubara, Y. Shimizu. History and Recent Development of Grain Oriented Electrical Steel at Kawasaki Steel. Kawasaki Steel Technical Report, 1998 (39), s. 3-12.

[3] Y. Wong, F. Fang, Y. Lu Zheng, Y. Xu, G. Gao, C. Li, R. Misra G. Wang. A Comparative Study of Microstructure and Texsture Evolution in $\mathrm{Cu}$-beariong and $\mathrm{Nb}$-bearing Grain Oriented Silicon Steels. Steel Research Int., 2017, 88 (3), s. 1600181 (1-8).

[4] X. Lu, F. Fang, Y. Zhang, Y. Wong, G. Yuan, Y. Xu, G. Gao, D. Misra, G. Wang. Influence of Rolling Reduction on Secondary Recrystalization and Magnetic Properties in Strip-Cast Grain-Oriented 4,5\% Si Steel. Steel Research Int., 2017, 88 (4), s. 1600255 (1-10).
[5] T. Kubota, M. Fujikura, Y. Ushigami. Recent Progress and future trend on grain-oriented silicon steel. Journal of Magnetism and Magnetic Materials, 2000, 215-216, s. 69-73.

[6] S. Suzuki, Y. Ushigami, H. Homma, S. Takebayashi, T. Kubota. Influence of Metallurgical Factors on Secondary Recrystallization of Silicon Steel. Materials Transactions, 2001, 42 (6), s. 994-1006.

[7] K. Price, B. Goode, D. Power. Grain-oriented electrical steels for power and distribution transformers. Ironmaking and Steelmaking, 2016, 43 (9), s. 636-641.

[8] Diffusion module (DICTRA) [Online] Dostępny z: https://www thermocalc.com/products-services/software/diffusion-module(dictra)/. 